Prepared in cooperation with the

New York State Department of Environmental Conservation and the

U.S. Environmental Protection Agency

\title{
Ground-Water Ouality in Western New York, 2006
}

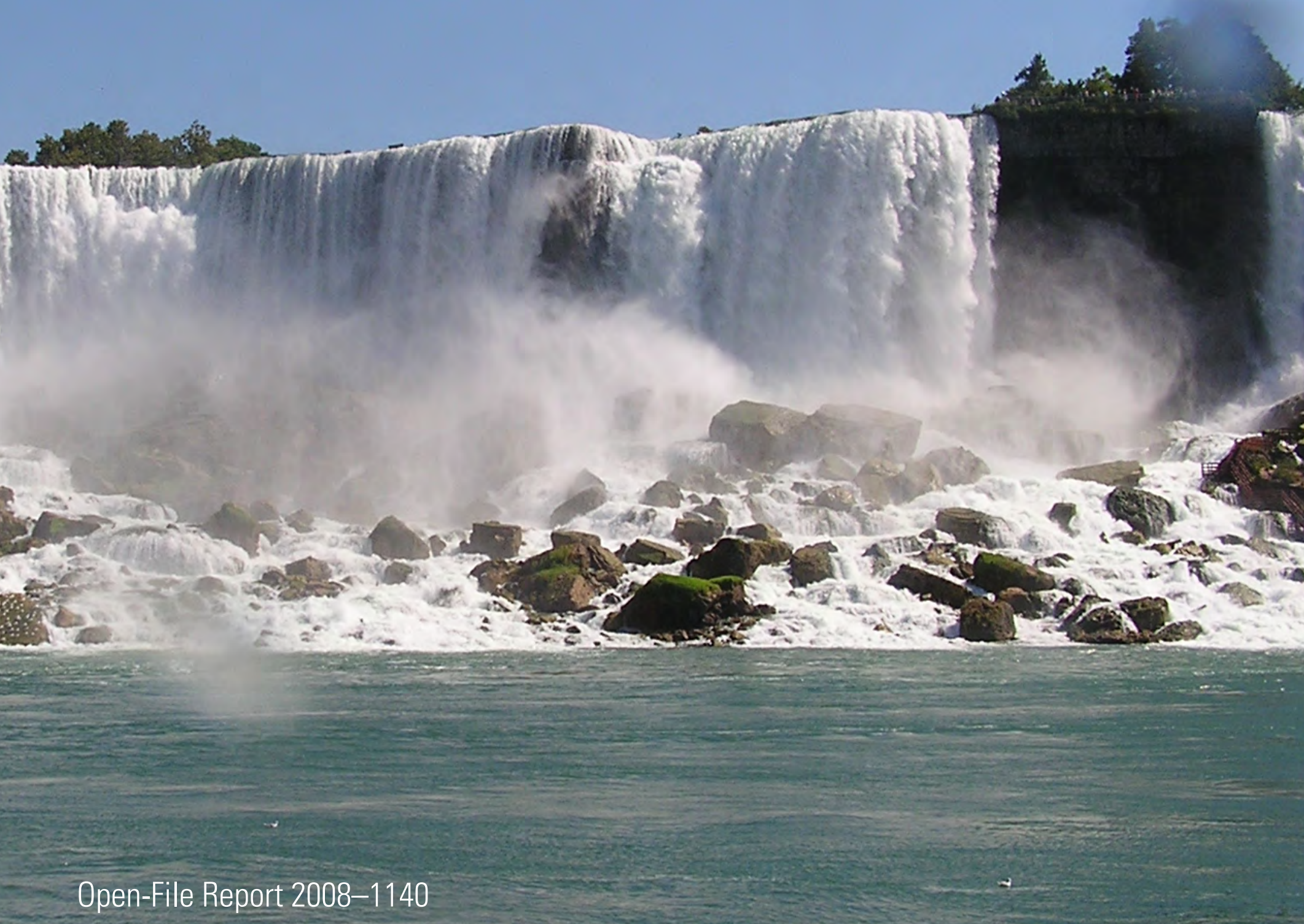

U.S. Department of the Interior

U.S. Geological Survey 
Cover. The American Falls viewed from the Niagara River at Niagara Falls, New York (photo by H.J. Zajd, Jr., 2007). 


\section{Ground-Water Quality in Western New York, 2006}

By David A.V. Eckhardt, James E. Reddy, and Kathryn L. Tamulonis

Prepared in cooperation with the

New York State Department of Environmental Conservation and the U.S. Environmental Protection Agency

Open-File Report 2008-1140 


\title{
U.S. Department of the Interior DIRK KEMPTHORNE, Secretary
}

\author{
U.S. Geological Survey \\ Mark D. Myers, Director
}

U.S. Geological Survey, Reston, Virginia: 2008

For more information on the USGS--the Federal source for science about the Earth, its natural and living resources, natural hazards, and the environment:

World Wide Web: http://www.usgs.gov

Telephone: 1-888-ASK-USGS

Any use of trade, product, or firm names is for descriptive purposes only and does not imply endorsement by the U.S. Government.

Although this report is in the public domain, permission must be secured from the individual copyright owners to reproduce any copyrighted materials contained within this report.

Suggested citation:

Eckhardt, D.A.V., Reddy, J.E., and Tamulonis, K.L., 2008, Ground-water quality in western New York, 2006: U.S. Geological Survey Open-File Report 2008-1140, 36 p., available only online at http://pubs.usgs.gov/ ofr/2008/1140 


\section{Contents}

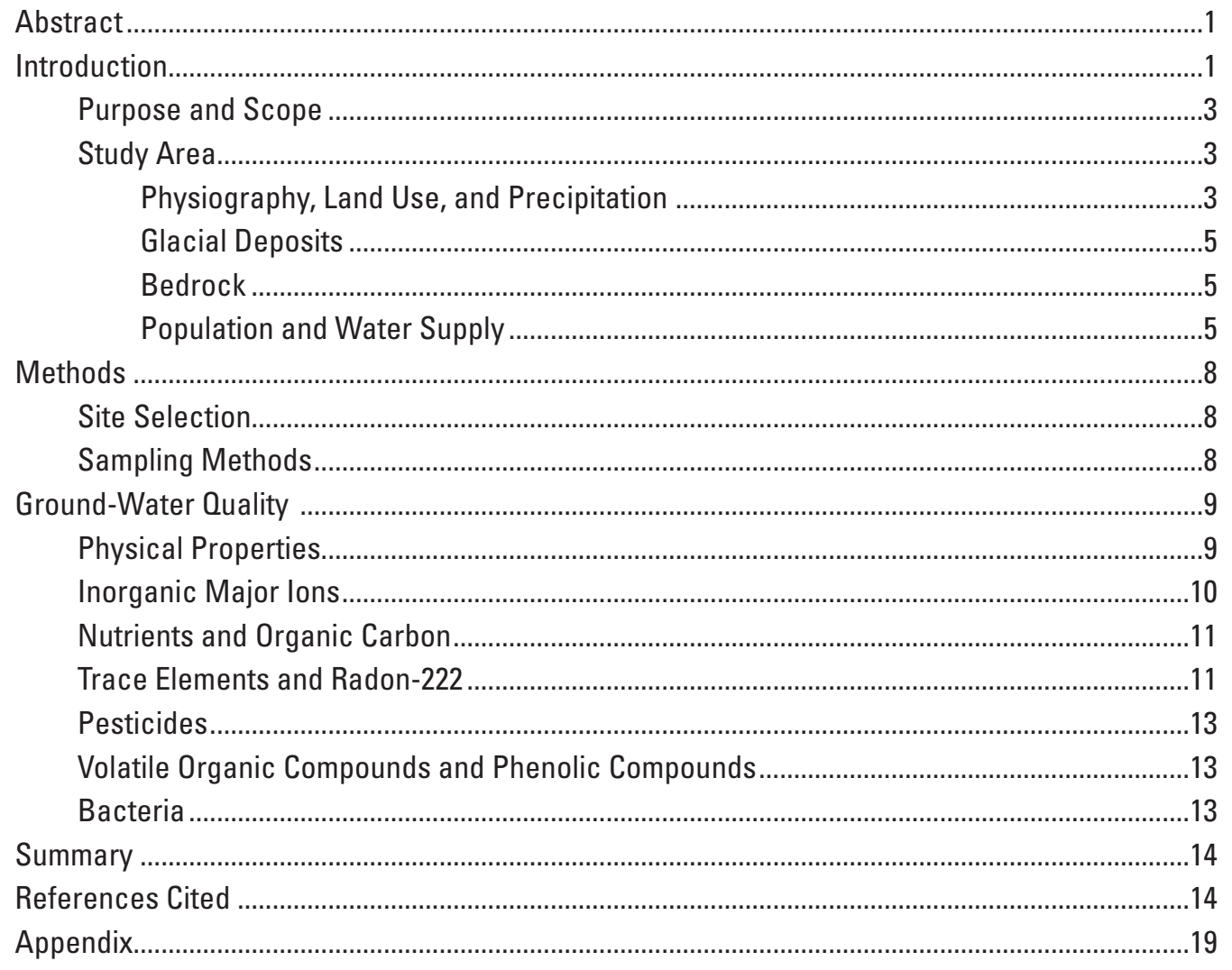

\section{Figures}

Maps 1-4 showing-

1. Pertinent geographic features of study area in western New York, and locations of the 33 wells sampled in 2006

2. Land use in western New York study area and locations of the 33 wells

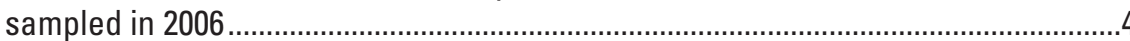

3. Surficial geology of western New York study area and locations of the 15 wells screened in sand and gravel aquifers that were sampled in 2006 .............6

4. Generalized bedrock geology of western New York study area and locations of the 18 wells completed in bedrock that were sampled in 2006.

\section{Tables}

1. Area and population of the western New York study area, by drainage basin

2. Summary statistics for concentrations of major ions in sand and gravel aquifers and bedrock aquifers in western New York, 2006.

3. Summary statistics for concentrations of nutrients and organic carbon in sand and gravel aquifers and bedrock aquifers in western New York, 2006

4. Summary statistics for concentrations of trace elements and radon-222 in sand and gravel aquifers and bedrock aquifers in western New York, 2006 


\section{Conversion Factors, Datum, and Abbreviations}

\begin{tabular}{lll}
\hline Multiply & By & To obtain \\
\hline & Length & \\
\hline inch (in.) & 2.54 & centimeter $(\mathrm{cm})$ \\
foot (ft) & 0.3048 & meter $(\mathrm{m})$ \\
square mile $\left(\mathrm{mi}^{2}\right)$ & 2.590 & square kilometer $\left(\mathrm{km}^{2}\right)$ \\
million gallons per day $(\mathrm{Mgal} / \mathrm{d})$ & 0.04381 & cubic meter per second $\left(\mathrm{m}^{3} / \mathrm{s}\right)$ \\
\hline
\end{tabular}

Temperature in degrees Celsius $\left({ }^{\circ} \mathrm{C}\right)$ may be converted to degrees Fahrenheit $\left({ }^{\circ} \mathrm{F}\right)$ as follows:

$$
{ }^{\circ} \mathrm{F}=\left(1.8 \times{ }^{\circ} \mathrm{C}\right)+32
$$

Vertical coordinate information is referenced to National Geodetic Vertical Datum of 1929 (NGVD 29).

Horizontal coordinate information is referenced to the North American Datum of 1983 (NAD 83).

\section{Abbreviations}

\begin{tabular}{|c|c|c|}
\hline AMCL & \multicolumn{2}{|c|}{ Alternative maximum contaminant level } \\
\hline $\mathrm{CFU} / \mathrm{ml}$ & \multicolumn{2}{|c|}{ Colony forming units per milliliter } \\
\hline CIAT & \multicolumn{2}{|c|}{ 2-chloro-4-isopropylamino-6-amino-s-triazine (also called deethylatrazine) } \\
\hline ESA & \multicolumn{2}{|c|}{ Ethanesulfonic acid } \\
\hline GWSI & \multicolumn{2}{|c|}{ Ground-Water Site Inventory } \\
\hline HA & \multicolumn{2}{|c|}{ Health Advisory for drinking water } \\
\hline HPC & \multicolumn{2}{|c|}{ Heterotrophic plate count } \\
\hline MCL & \multicolumn{2}{|c|}{ Maximum contaminant level } \\
\hline MTBE & \multicolumn{2}{|c|}{ Methyl-tert-butyl ether } \\
\hline NWOL & \multicolumn{2}{|c|}{ USGS National Water Quality Laboratory } \\
\hline NYSDEC & \multicolumn{2}{|c|}{ New York State Department of Environmental Conservation } \\
\hline NYSDOH & \multicolumn{2}{|c|}{ New York State Department of Health } \\
\hline $\mathrm{OA}$ & \multicolumn{2}{|l|}{ Oxanilic acid } \\
\hline OGRL & \multicolumn{2}{|c|}{ USGS Organic Geochemistry Research Laboratory } \\
\hline SMCL & \multicolumn{2}{|c|}{ Secondary maximum contaminant level } \\
\hline USEPA & \multicolumn{2}{|c|}{ U.S. Environmental Protection Agency } \\
\hline USGS & \multicolumn{2}{|c|}{ U.S. Geological Survey } \\
\hline VOC & \multicolumn{2}{|c|}{ Volatile organic compound } \\
\hline \multicolumn{3}{|c|}{ Other abbreviations in this report: } \\
\hline \multicolumn{2}{|c|}{ micrometer } & $\mu \mathrm{m}$ \\
\hline \multicolumn{2}{|c|}{ micrograms per liter } & $\mu \mathrm{g} / \mathrm{L}$ \\
\hline \multicolumn{2}{|c|}{ milligrams per liter } & $\mathrm{mg} / \mathrm{L}$ \\
\hline \multirow{2}{*}{\multicolumn{2}{|c|}{$\begin{array}{l}\text { microsiemens per centimeter } \\
\text { platinum-cobalt units }\end{array}$}} & $\mu \mathrm{S} / \mathrm{cm}$ \\
\hline & & Pt-Co units \\
\hline \multicolumn{3}{|c|}{ picocuries per liter } \\
\hline
\end{tabular}




\title{
Ground-Water Quality in Western New York, 2006
}

\author{
By David A.V. Eckhardt, James E. Reddy, and Kathryn L. Tamulonis
}

\section{Abstract}

Water samples were collected from 7 production wells and 26 private residential wells in western New York from August through December 2006 and analyzed to characterize the chemical quality of ground water. Wells at 15 of the sites were screened in sand and gravel aquifers, and 18 were finished in bedrock aquifers. The wells were selected to represent areas of greatest ground-water use and to provide a geographical sampling from the 5,340-square-mile study area. Samples were analyzed for 5 physical properties and 219 constituents that included nutrients, major inorganic ions, trace elements, radionuclides, pesticides, volatile organic compounds (VOC), phenolic compounds, organic carbon, and bacteria.

Results indicate that ground water used for drinking supply is generally of acceptable quality, although concentrations of some constituents or bacteria exceeded at least one drinking-water standard at 27 of the 33 wells. The cations that were detected in the highest concentrations were calcium, magnesium, and sodium; anions that were detected in the highest concentrations were bicarbonate, chloride, and sulfate. The predominant nutrients were nitrate and ammonia; nitrate concentrations were higher in samples from sand and gravel aquifers than in samples from bedrock. The trace elements barium, boron, copper, lithium, nickel, and strontium were detected in every sample; the trace elements with the highest concentrations were barium, boron, iron, lithium, manganese, and strontium. Eighteen pesticides, including 9 pesticide degradates, were detected in water from 14 of the 33 wells, but none of the concentrations exceeded State or Federal Maximum Contaminant Levels (MCLs). Fourteen volatile organic compounds were detected in water from 12 of the 33 wells, but none of the concentrations exceeded MCLs.

Eight chemical analytes and three types of bacteria were detected in concentrations that exceeded Federal and State drinking-water standards, which are typically identical. Sulfate concentrations exceeded the U.S. Environmental Protection Agency (USEPA) Secondary Maximum Contaminant Level (SMCL) of 250 milligrams per liter (mg/L) in three samples, and chloride concentrations exceeded the SMCL of $250 \mathrm{mg} / \mathrm{L}$ in two samples. Sodium concentrations exceeded the USEPA Drinking Water Health Advisory of $60 \mathrm{mg} / \mathrm{L}$ in nine samples. Iron concentrations exceeded the SMCL of $300 \mu \mathrm{g} / \mathrm{L}$ (micrograms per liter) in 14 filtered samples, and manganese exceeded the USEPA SMCL of $50 \mu \mathrm{g} / \mathrm{L}$ in 15 filtered samples, as well as the New York State MCL of $300 \mu \mathrm{g} / \mathrm{L}$ in 1 filtered sample. Arsenic exceeded the USEPA MCL of $10 \mu \mathrm{g} / \mathrm{L}$ in two samples, aluminum exceeded the SMCL for aluminum of $50 \mu \mathrm{g} / \mathrm{L}$ in one sample, and lead exceeded the MCL of $15 \mu \mathrm{g} / \mathrm{L}$ in one sample. Radon-222 exceeded the proposed USEPA MCL of 300 picocuries per liter in 24 samples. Any detection of coliform bacteria indicates a violation of New York State health regulations; total coliform was detected in 12 samples, and Escherichia coli was detected in 2 samples. The plate counts for heterotrophic bacteria exceeded the MCL (500 colony-forming units per milliliter) in four samples.

\section{Introduction}

Water samples were collected from 7 production wells and 26 private residential wells in the 9 westernmost counties of New York from August through December 2006 and analyzed to characterize the chemical quality of ground water in the 5,340-mi² study area. All 33 wells were within 3 river or lake basins (fig. 1); 16 were in the Lake Erie and Niagara River Basin, 7 were in the western Lake Ontario Basin, which lies between the Niagara River and the Genesee River Basins, and 10 were in the Allegheny River Basin. Fifteen of the wells were screened in sand and gravel aquifers, and 18 were completed in bedrock aquifers.

Many studies of ground-water quality in New York have included parts of the study area, such as Crain (1966), La Sala (1968), Frimpter (1974), Moore and Staubitz (1984), Erie County (1985), Koszalka and others (1985), and Anderson and others (2000). These studies provide much useful information, but a comprehensive and current assessment of the ground-water quality throughout the entire area is needed.

Section 305(b) of the Federal Clean Water Act Amendments of 1977 (U.S. Environmental Protection Agency, 1997) requires all States to implement a comprehensive water-quality-monitoring program for surface-water and ground-water 


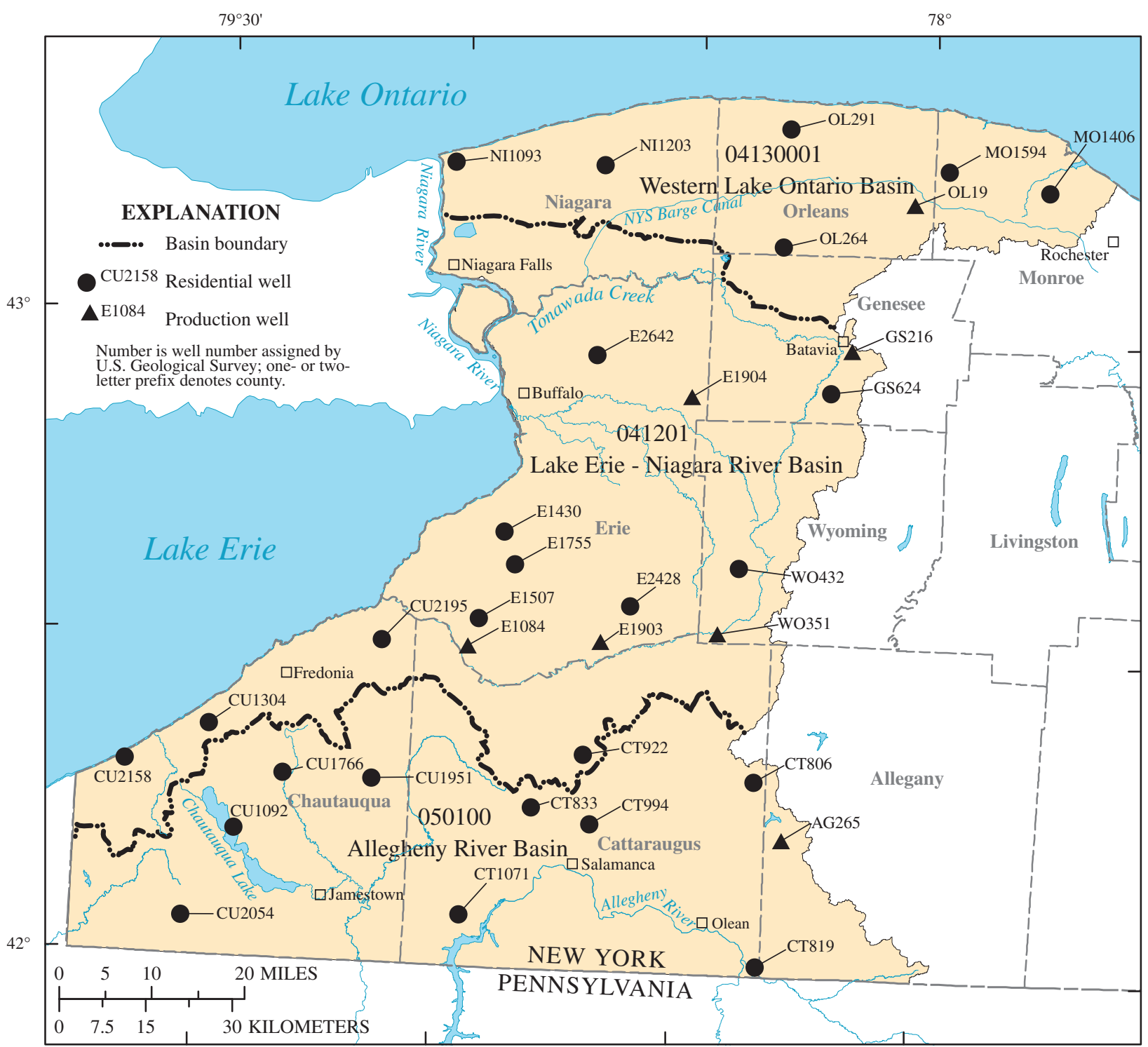

Base from U.S. Geological Survey, Seamless Data Distribution System, accessed in 2007 at http://seamless.usgs.gov

Universal Transverse Mercator projection, Zone 18
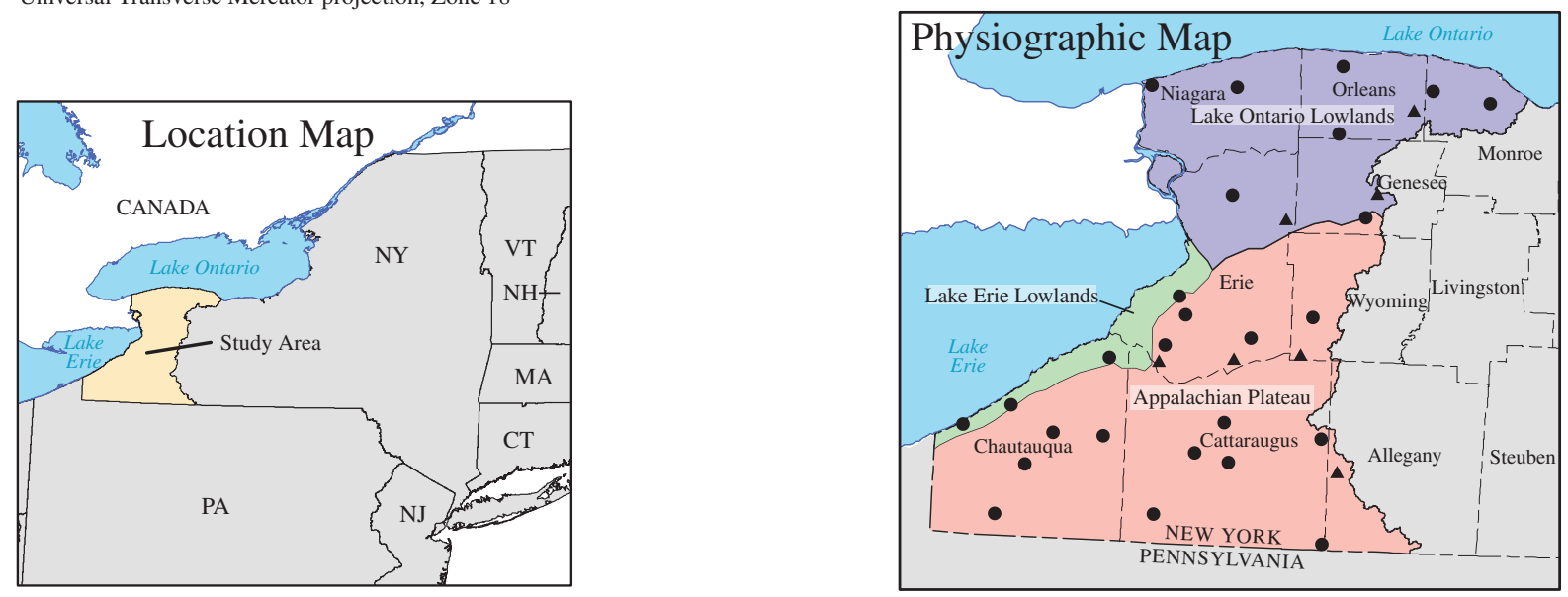

Figure 1. Pertinent geographic features of study area in western New York, and locations of the 33 wells sampled in 2006. (Well data are given in table $\mathrm{A} 1$ at end of report.) 
resources. In 2001, the U.S. Geological Survey (USGS), in cooperation with the New York State Department of Environmental Conservation (NYSDEC) and the U.S. Environmental Protection Agency (USEPA), began an assessment of ground-water quality in major river basins throughout the State, as specified in Section 305(b). To date (2008), ground-water-quality studies have been completed in the Chemung River Basin (Hetcher-Aguila, 2004), the Lake Champlain Basin (Nystrom, 2006), the upper Susquehanna River Basin (Hetcher-Aguila and Eckhardt, 2006), the Delaware River Basin (Nystrom, 2007a), the St. Lawrence River Basin (Nystrom, 2007b), the Genesee River Basin (Eckhardt and others, 2007), and the Mohawk River Basin (Nystrom, 2008). In 2006, a study of the westernmost region of New York was completed and is the subject of this report.

\section{Purpose and Scope}

This report presents the results of the 2006 ground-water study in western New York. It first describes the study area and the sampling methods, then presents results of the water-quality analyses. Summary statistics (number of samples exceeding Federal or State drinking-water standards) and the minimum, median, and maximum concentrations of all analytes in surficial and bedrock aquifers are given in tables 1-4; detailed analytical results are given in Appendix tables A1-A9 (at end of report). Analytical results for selected constituents are compared with Federal and State drinking-water standards, which are typically identical. The standards include Maximum Contaminant Levels (MCLs), Secondary Maximum Contaminant Levels (SMCLs), and Health Advisories (HAs) established by the USEPA (2002; 2004; and 2006) and the New York State Department of Health (NYSDOH) (2006). MCLs specify the highest level of a contaminant that is allowed in drinking water; they are based on human health criteria and are legally enforceable by Federal and State authorities. SMCLs are non-enforceable guidelines based on cosmetic and aesthetic criteria, such as taste and odor. HAs are estimates of acceptable drinking water levels for contaminants that can effect human health; they are non-enforceable standards that provide technical guidance for water use.

\section{Study Area}

The study area includes all of Chautauqua, Erie, and Niagara Counties and most of Cattaraugus and Orleans Counties; it also includes the western parts of Allegany, Genesee, Monroe, and Wyoming Counties (fig. 1). It encompasses parts of the Lake Erie and Niagara River Basin, the western Lake Ontario Basin (between the Niagara River and the Genesee River Basins), and the Allegheny River Basin (fig. 1, table 1). The parts of these drainage basins that lie outside New York's boundaries were not included in this study.

\section{Physiography, Land Use, and Precipitation}

The central, southern, and eastern parts of the study area lie within the Appalachian Plateau physiographic province (fig. 1, table A1); the northern part lies in the Lake Ontario Lowlands province, and the western part lies in the Lake Erie Lowlands province. Forest and pasture dominate the uplands and narrow valleys of the southern and eastern parts of the study area; cultivation of row crops, apples, and grapes is common in the Lake Erie and Lake Ontario Lowlands; and row-crop, forage-crop, and dairy farming is concentrated in a band of fertile soils between Buffalo and Rochester (fig. 2). The Buffalo and Niagara Falls metropolitan area lies near the outlet of Lake Erie and extends northward along the Niagara River. The study

Table 1. Area and population of the western New York study area, by drainage basin'.

[Locations are shown in fig. 1]

\begin{tabular}{lccr}
\hline \multicolumn{1}{c}{ Drainage basin } & Hydrologic unit code & Area (square miles) & Population $^{2}$ \\
\hline Lake Erie and Niagara River & 041201 & 2,378 & $1,239,000$ \\
Lake Ontario, west of Genesee River ${ }^{3}$ & 04130001 & 1,035 & 568,000 \\
Allegheny River & 050100 & 1,927 & 159,000 \\
\hline
\end{tabular}

${ }^{1}$ Data represent the part of basin that lies in New York State.

22000 Census (U.S. Department of Commerce, 2000).

${ }^{3}$ Basin area excludes Genesee River Basin. 


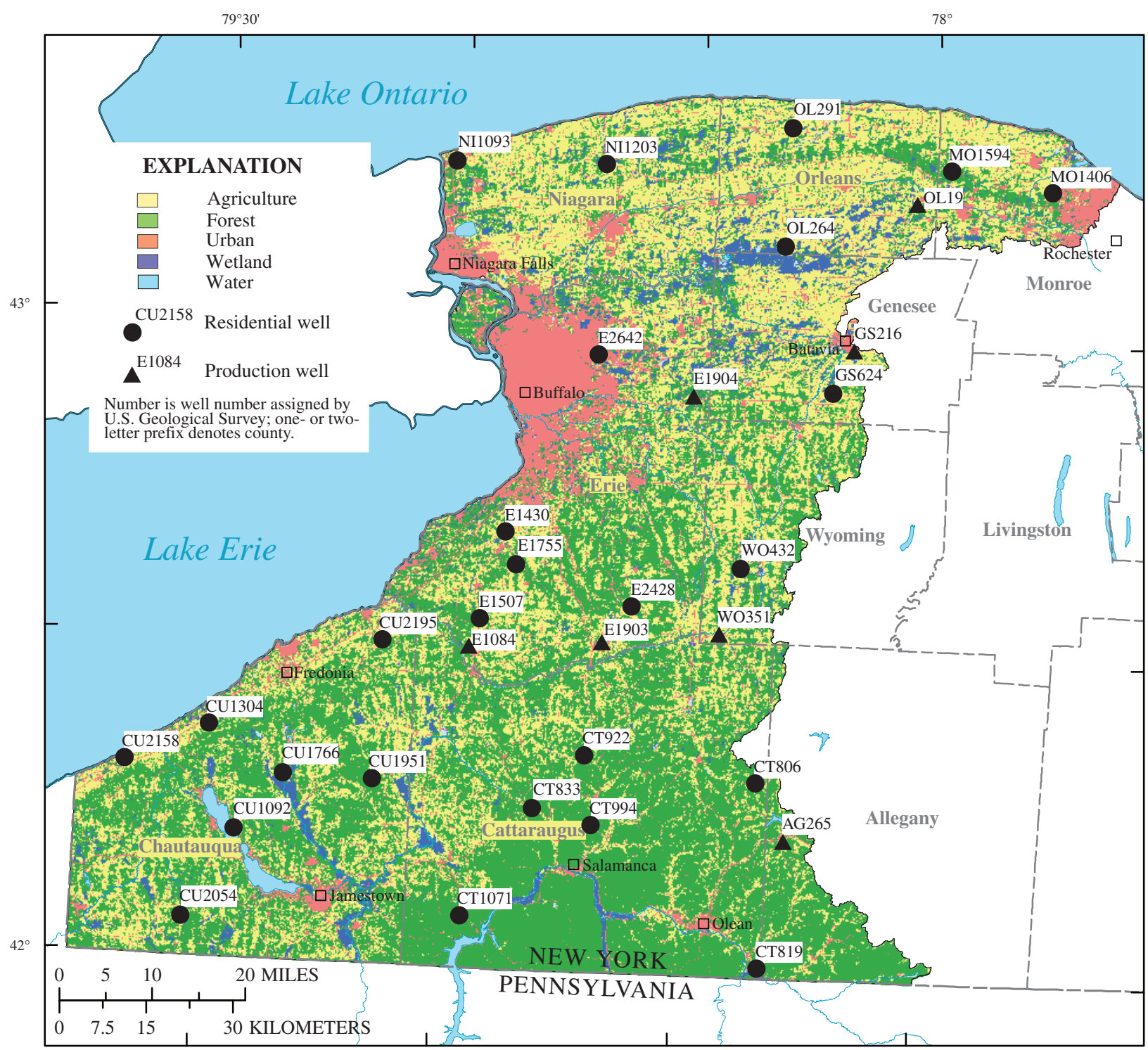

Base from U.S. Geological Survey, Seamless Data Distribution System,

accessed in 2007 at http://seamless.usgs.gov

Universal Transverse Mercator projection, Zone 18

Land use from National Land Cover Data 1992

Resolution 1 arc-second (approx. 30m)

Figure 2. Land use in western New York study area and locations of the 33 wells sampled in 2006. (Well data are given in table A1.) 
area contains several small lakes, such as Chautauqua Lake, and is crossed by the New York State Barge (Erie) Canal, which traverses the State from Albany to Buffalo.

Land-surface elevations range from about $250 \mathrm{ft}$ at Lake Ontario and $320 \mathrm{ft}$ at Lake Erie to about 2,500 ft in the eastern and southern uplands. The climate is humid, and air temperatures are moderated by Lake Ontario and Lake Erie. Precipitation ranges from about $50 \mathrm{in} / \mathrm{yr}$ in the southwestern area near Jamestown (fig. 1) to about $30 \mathrm{in} / \mathrm{yr}$ along the Lake Ontario shore; mean annual precipitation is about $40 \mathrm{in}$. About 15 percent of the annual precipitation infiltrates the land surface and recharges the sand and gravel and bedrock aquifers (Randall, 2001).

\section{Glacial Deposits}

Glacially derived deposits are generally present throughout New York, except in an area around Salamanca in southern Cattaraugus County that was not covered by glacial ice (fig. 3), where a thin layer of colluvium is formed from weathered bedrock. Glaciers scoured the hills and valleys of New York and left a thin mantle of till on top of the bedrock in upland areas and morainal deposits of fine-grained, poorly sorted material that formed valley plugs and low ridges. During the subsequent period of deglaciation, meltwater streams deposited thick layers of stratified drift (fluvial sand and gravel) in front of the glaciers and on top, beneath, and alongside them, to form deposits that are seen today as outwash plains, eskers, kettles, kames, and kame terraces. Glacial meltwaters also deposited fine particles in proglacial lakes, where they settled to form poorly permeable deposits of lacustrine clay, silt, and fine sand. Recent alluvium covers some of the glacial deposits and forms today's flood plains along the larger streams and rivers and on the terraces along the lake shores. The glacial deposits within the study area are described in detail by Fairchild (1928), Coates (1966), Gilbert and Kammerer (1971), Frimpter (1974; 1986), Miller and Staubitz (1985), Cadwell and Muller (1986), Miller (1988), Yager and others (1997), and Randall (2001).

\section{Bedrock}

The bedrock aquifers in the study area (fig. 4) consist of relatively flat-lying, interbedded sedimentary units of shale, siltstone, sandstone, limestone, and dolostone of Ordovician, Silurian, and Devonian age (Broughton and others, 1962; Johnston, 1964; Staubitz and Miller, 1987; Brett and others, 1995; Kappel and Miller, 1996). Two bands of carbonate-rock aquiferslimestones and dolostones-extend from Buffalo to Batavia and from Niagara Falls to Rochester; interbedded shale, dolostone, and evaporites crop out in the area between the carbonate-rock aquifers.

\section{Population and Water Supply}

The southern and eastern parts of the study area are predominantly rural, although they contain several small cities (Batavia, Fredonia, Jamestown, and Olean) (fig. 1) and many small villages and hamlets. Most of the developed, urban area is in the cities of Buffalo and Niagara Falls, their suburbs in Erie and Niagara Counties, and in part of the Rochester metropolitan area in Monroe County (fig. 2). Total population of the study area in 2000 was about 1,966,000, about half of which lives in the Buffalo and Niagara Falls area (U.S. Department of Commerce, 2000). Production wells provide water to about 40,000 people in the villages, towns, and cities within the study area (New York State Department of Health, 2005).

The largest water suppliers are the Erie County Water Authority and the Niagara Falls Water Authority, which provide the residents of these areas with water from Lake Erie and the Niagara River, respectively. The Monroe County Water Authority provides residents in Monroe, eastern Orleans, and northeastern Genesee Counties with water from Lake Ontario. Many of the rural communities and residents in areas that lie beyond these water-system service areas rely on ground water from bedrock or from surficial deposits of sand and gravel. Some community systems in areas where surficial aquifers are thin or absent use surface water from small reservoirs or lakes; others obtain water from bedrock wells. Most rural homeowners that live beyond the service areas of community water systems have private wells that tap surficial deposits or bedrock.

The most productive aquifers within the study area are the glacial and alluvial deposits of sand and gravel (fig. 3). Frimpter (1974) estimated that sand and gravel aquifers in the Allegheny River valley can yield more than $220 \mathrm{Mgal} / \mathrm{d}$. Deltaic sand and gravel deposits that are tapped for water supply at Jamestown may potentially yield $10 \mathrm{Mgal} / \mathrm{d}$ (Crain, 1966), and outwash deposits at Batavia yield as much as $1.4 \mathrm{Mgal} / \mathrm{d}$ (Cosner, 1984). Till deposits are typically thin and relatively impermeable and yield little water to wells. Clay beds yield little or no water to wells but may overlie productive sand and gravel aquifers. Bedrock aquifers (fig. 4) are used for water supply where sand and gravel aquifers are absent, typically in upland areas. The bedrock aquifers in the study area may yield water of poorer chemical quality than the surficial aquifers; for example, the carbonate-rock aquifers typically yield very hard water, whereas shale bedrock aquifers along the shores of Lake Erie and Lake Ontario Lowlands often yield salty water at depths greater than $50 \mathrm{ft}$ (Frimpter, 1974; La Sala, 1968). 


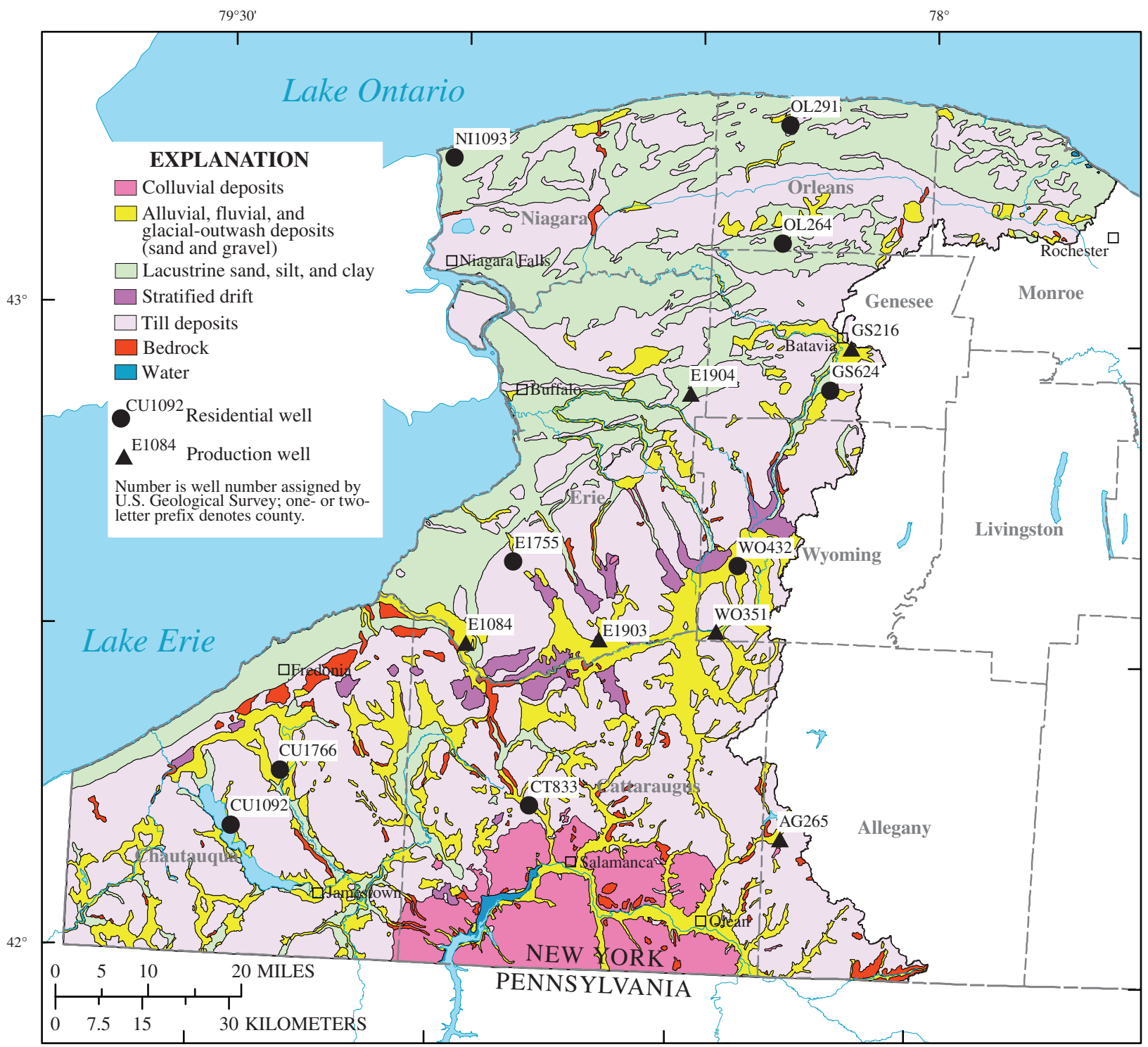

Base from U.S. Geological Survey, Seamless Data Distribution System,

accessed in 2007 at http://seamless.usgs.gov

Universal Transverse Mercator projection, Zone 18

Surficial Geology from New York State Museum, 1:250,000

Figure 3. Surficial geology of western New York study area and locations of the 15 wells screened in sand and gravel aquifers that were sampled in 2006. (Well data are given in table A1.) 


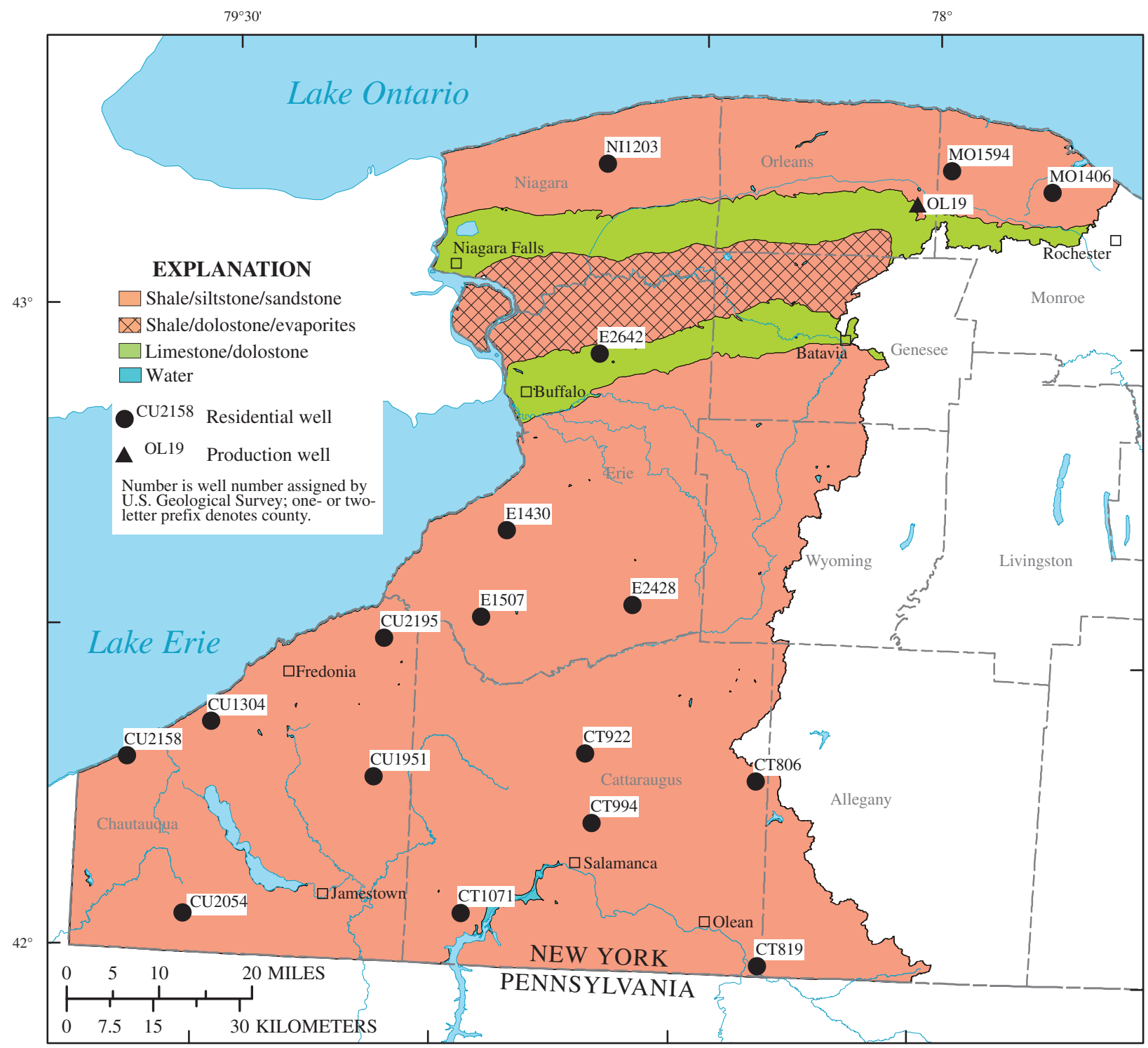

Base from U.S. Geological Survey, Seamless Data Distribution System,

accessed in 2007 at http://seamless.usgs.gov
Universal Transverse Mercator projection, Zone 18

Bedrock Geology from New York State Museum, 1:250,000

Figure 4. Generalized bedrock geology of western New York study area and locations of the 18 wells completed in bedrock that were sampled in 2006. (Well data are given in table A1.) 


\section{Methods}

A total of 33 wells were selected for sample collection-15 were finished in sand and gravel aquifers (fig. 3), and 18 were finished in bedrock aquifers (fig. 4). The 15 wells that tap sand and gravel consisted of 6 production wells and 9 private residential wells; the 18 bedrock wells consisted of 1 production well and 17 private residential wells. Sampling was done from August through December 2006. The water samples were analyzed for 5 physical properties and 219 constituents, including 4 types of bacteria. Three samples - two field blanks and one replicate sample-were collected for quality assurance (QA) and quality control (QC), as required for the Federal 305(b) program.

\section{Site Selection}

The wells were identified through (1) the USGS Ground-Water Site Inventory (GWSI) database, (2) the NYSDEC Water-Well Reporting Program, and (3) information from State and county health departments. The Water-Well Reporting Program was implemented in 2000 to collect information about newly drilled wells throughout New York from licensed well drillers; the resulting database provides useful information for ground-water studies. A letter requesting permission to sample the water was sent to owners of residential wells that were identified as potential sampling sites; the letter described the project and included a questionnaire asking the location of the well, the most convenient times for sampling, any safety concerns around the well, and other information.

Production wells were identified through the NYSDOH and by local officials from the Allegany, Erie, Genesee, Niagara, and Wyoming County Departments of Health and water managers of villages and cities throughout the study area. The water managers were sent a project description and a questionnaire similar to those sent to residential well owners. Well owners who responded favorably were contacted by telephone to clarify information about the wells and to arrange sampling dates.

Most of the wells finished in sand and gravel (fig. 3) were in valleys and ranged from 15 to $185 \mathrm{ft}$ deep (table A1). All the production wells that tap sand and gravel have slotted screens, whereas most residential wells that tap sand and gravel simply have an open-bottomed steel casing. The bedrock wells (fig. 4) were generally in upland terrains and ranged from 27 to $210 \mathrm{ft}$ deep (table A1); these wells typically have steel casing set into open boreholes in competent rock.

Site selection did not target specific municipalities, industries, or agricultural practices; rather, sampling sites were selected to represent areas of greatest ground-water use and to obtain a geographical representation of the study area and its aquifers (figs. 2-4). Site selection included wells in each of four predominant land-use categories—agriculture, urban, forest, and wetland. The land-use classification was done through satellite-image analysis of the predominant land uses within a half-mile radius of each well (fig. 2). Most were surrounded by a predominant land use that represented more than 50 percent of the radial area surrounding the well; the other wells were surrounded by a combination of land uses.

Shallow wells that tap sand and gravel aquifers are susceptible to contamination by several types of compounds, including volatile organic compounds (VOCs), pesticides, deicing chemicals, and nutrients from nearby highways and industrial, agricultural, and residential areas. The movement of these contaminants to the water table through the soils and surficial sand and gravel can be relatively rapid. Bedrock wells that tap sandstone and shale aquifers in rural upland areas are generally less susceptible to contamination from industrial and urban sources, which are mainly in the valleys; but bedrock wells in lowland areas underlain by carbonate rock (limestone and dolostone) may be vulnerable to contamination from surface runoff because infiltration rates and ground-water flow can be relatively rapid through solution features in the rock. Agricultural land that surrounds wells may be a potential source of contamination from fertilizers, pesticides, and fecal waste from livestock; lawns and septic systems are also a potential source of these contaminants. In addition to human contaminants, the aquifers contain naturally derived elements that may diminish water quality, such as sodium, chloride, sulfate, iron, manganese, and trace elements such as arsenic; some also may contain hydrogen sulfide, methane, and radon gases from deep-lying sources.

\section{Sampling Methods}

Water samples were analyzed for the physical properties and constituents listed in Appendix tables A2-A9 (at end of report). The categories are as follows: physical properties (table A3), inorganic constituents (table A4), nutrients and total organic carbon (table A5), trace elements and radon-222 (table A6), and VOCs and phenols (table A8). Samples were collected from every well for these analyses and were processed by methods described in the USGS manual for the collection of waterquality data (U.S. Geological Survey, 2006). Additionally, pesticide samples were collected for pesticide analyses (table A7) 
and processed by the methods of Shelton (1994) and Sandstrom and others (2001). These samples were analyzed at the USGS National Water Quality Laboratory (NWQL) and the USGS Kansas Organic Geochemistry Research Laboratory (OGRL) for 134 pesticides and pesticide degradates through methods described by Zaugg and others (1995), Furlong and others (2001), Meyer and others (1993), and Lee and Strahan (2003). The analytical method devised by Zaugg and others (1995) was developed in cooperation with the USEPA and allows detection of the nation's most commonly used pesticides. Samples for bacteria analyses (table A9) were processed in accordance with NYSDOH guidelines.

Sampling was done at all sites as follows: the well pump was turned on (many of the production wells were already running) and allowed to run until at least five casing-volumes of well water had passed the sampling point. A raw-water tap between the well and the pressure tank was opened, and the water was allowed to flush for several minutes. During this time, a general visual evaluation of the area surrounding the well was conducted to identify potential sources of contamination that could affect the well water. Samples were collected from the raw-water tap to avoid all water-treatment systems and to ensure that the water collected was representative of the water in the aquifer. A Teflon discharge line was then connected to the tap, and samples were analyzed with a multiprobe meter for physical properties (temperature, specific conductance, dissolved-oxygen concentration, and $\mathrm{pH}$ ). After the measurements of these properties had stabilized, a second Teflon discharge line was connected to the first with a stainless-steel quick-connect fitting and was directed into a sample-collection chamber mounted upon a plastic box; this chamber was used to minimize sample exposure to dust and other potential sources of contamination. Bottles were filled within the chamber according to standard USGS field methods (U.S. Geological Survey, 2006).

The analyses for physical properties, most trace elements and metals, acid-neutralizing capacity, organic carbon, radon-222, VOCs, and phenols were done on unfiltered water samples to obtain total whole-water concentrations. Dissolved concentrations of nutrients, major inorganic constituents, three metals, and pesticides were obtained from filtered samples. Concentrations of iron and manganese in unfiltered samples were compared with those in filtered samples to obtain the difference between the total and dissolved concentrations (table A6). Sulfuric acid was added to the samples collected for phenol analysis, hydrochloric acid was added to samples collected for total organic carbon and VOC analyses, and nitric acid was added to some of the samples collected for trace-element analyses to prevent sample degradation. Samples collected for dissolved inorganic-compound analyses were filtered through a 0.45 -micrometer $(\mu \mathrm{m})$ cellulose capsule filter that was attached to the Teflon discharge line inside the sample-collection chamber; samples for pesticide analysis were filtered through a 0.7 - $\mu$ m furnace-baked glass-fiber plate filter.

All Teflon discharge lines were cleaned in the laboratory before each sampling day and in the field between each sample collection. New bags were used at each sampling site. Samples for radon analysis were obtained through an in-line septum chamber with a disposable syringe to avoid atmospheric contamination. Samples for bacterial analysis were collected in sterile containers provided by the bacteriological laboratory; the connection of the sampling tube to the well tap was not sterilized.

The samples were stored on ice in coolers and delivered directly, or shipped by overnight delivery, to one of four laboratories: (1) the USGS NWQL in Denver, Colo., for analysis for inorganic major ions, nutrients, inorganic trace elements and radon-222, some pesticides, and VOCs (U.S. Geological Survey, 2007); (2) the USGS Kansas OGRL in Lawrence, Kans., for other pesticides; (3) a New York State-certified private laboratory in Waverly, N.Y., for total organic carbon and phenolic compounds; and (4) a laboratory in Lackawanna, N.Y., approved by New York State for bacteria analysis.

\section{Ground-Water Quality}

The 33 ground-water samples collected during this study were analyzed for 5 physical properties and 219 constituents. Most (137) of the 215 chemical constituents were not detected in any sample (table A2). The concentrations of the 78 detected chemical constituents are listed in tables A4-A8, and the results for 4 types of bacteria are listed in table A9. The quality of the sampled ground water was generally acceptable, except where concentrations of certain constituents exceeded recommended MCLs, SMCLs, or HAs set by the U.S. Environmental Protection Agency (2006) and the New York State Department of Health (2006).

The QA/QC field blanks contained no constituent in concentrations above the laboratory reporting levels; this indicates that no contamination had occurred through the sampling or analytical procedures. The results of the two QA/QC replicate samples indicated that variability in sample results met the precision requirements of the study. The analytes with the largest percent differences between concentration in a ground-water sample and that in the replicate sample were acid-neutralizing capacity, residue on evaporation, and low-concentration trace elements (concentrations near the reporting level for the elements). 


\section{Physical Properties}

The $\mathrm{pH}$ of the samples (table A3) ranged from 6.4 to 8.2 ; $\mathrm{pH}$ of 1 of the 33 samples was outside the accepted SMCL range of 6.5 to 8.5 (U.S. Environmental Protection Agency, 2006). Specific conductance of the samples ranged from 171 to $5,500 \mu \mathrm{S} / \mathrm{cm}$. Dissolved-oxygen concentrations ranged from less than $0.3 \mathrm{mg} / \mathrm{L}$ at four wells to $6.7 \mathrm{mg} / \mathrm{L}$. None of the samples had a water color that exceeded the SMCL of 15 platinum-cobalt units. The odor of hydrogen sulfide gas was noted by field personnel in water from 10 of the 33 wells.

\section{Inorganic Major lons}

Water from the wells was generally a calcium-bicarbonate type, although water from three wells-CT 994, CU 1304, and CU 1766 (fig. 1) — was a sodium-bicarbonate type; water from two wells (CU 2158 and E 2642) was a calcium-sulfate type; water from two wells (AG 265 and MO 1594) was a calcium-chloride type; and water from one well (NI 1203) was a sodiumchloride type (Hem, 1985). The cations that were detected in the highest concentrations were calcium, magnesium, and sodium (tables 2 and A4). Calcium concentrations ranged from 6.04 to $197 \mathrm{mg} / \mathrm{L}$, and magnesium concentrations ranged from 1.46 to $57.4 \mathrm{mg} / \mathrm{L}$. Calcium and magnesium contribute to water hardness, and 18 of the 33 wells yielded water with hardness greater than $180 \mathrm{mg} / \mathrm{L}$, which is classified as "very hard" (Hem, 1985). Sodium concentrations ranged from 2.87 to $929 \mathrm{mg} / \mathrm{L}$, and nine samples exceeded the USEPA Health Advisory, which recommends that sodium concentrations in drinking water not exceed $60 \mathrm{mg} / \mathrm{L}$ to minimize the taste. This HA for sodium is not federally enforceable but is intended as a guideline for consumers (U.S. Environmental Protection Agency, 2002; 2006).

The anions that were detected in the highest concentrations were bicarbonate (alkalinity), chloride, and sulfate (tables 2 and A4). Bicarbonate concentrations ranged from 90 to $486 \mathrm{mg} / \mathrm{L}$ (as $\mathrm{CaCO}_{3}$ ), chloride concentrations ranged from 0.78 to $1,590 \mathrm{mg} / \mathrm{L}$, and sulfate concentrations ranged from less than 0.18 to $371 \mathrm{mg} / \mathrm{L}$. The chloride SMCL of $250 \mathrm{mg} / \mathrm{L}$ was exceeded in two samples, and the sulfate SMCL of $250 \mathrm{mg} / \mathrm{L}$ was exceeded in three samples.

Table 2. Summary statistics for concentrations of major ions in sand and gravel aquifers and bedrock aquifers in western New York, 2006.

[Concentrations are in milligrams per liter. All samples represent filtered water; No., number; --, not applicable; <, less than]

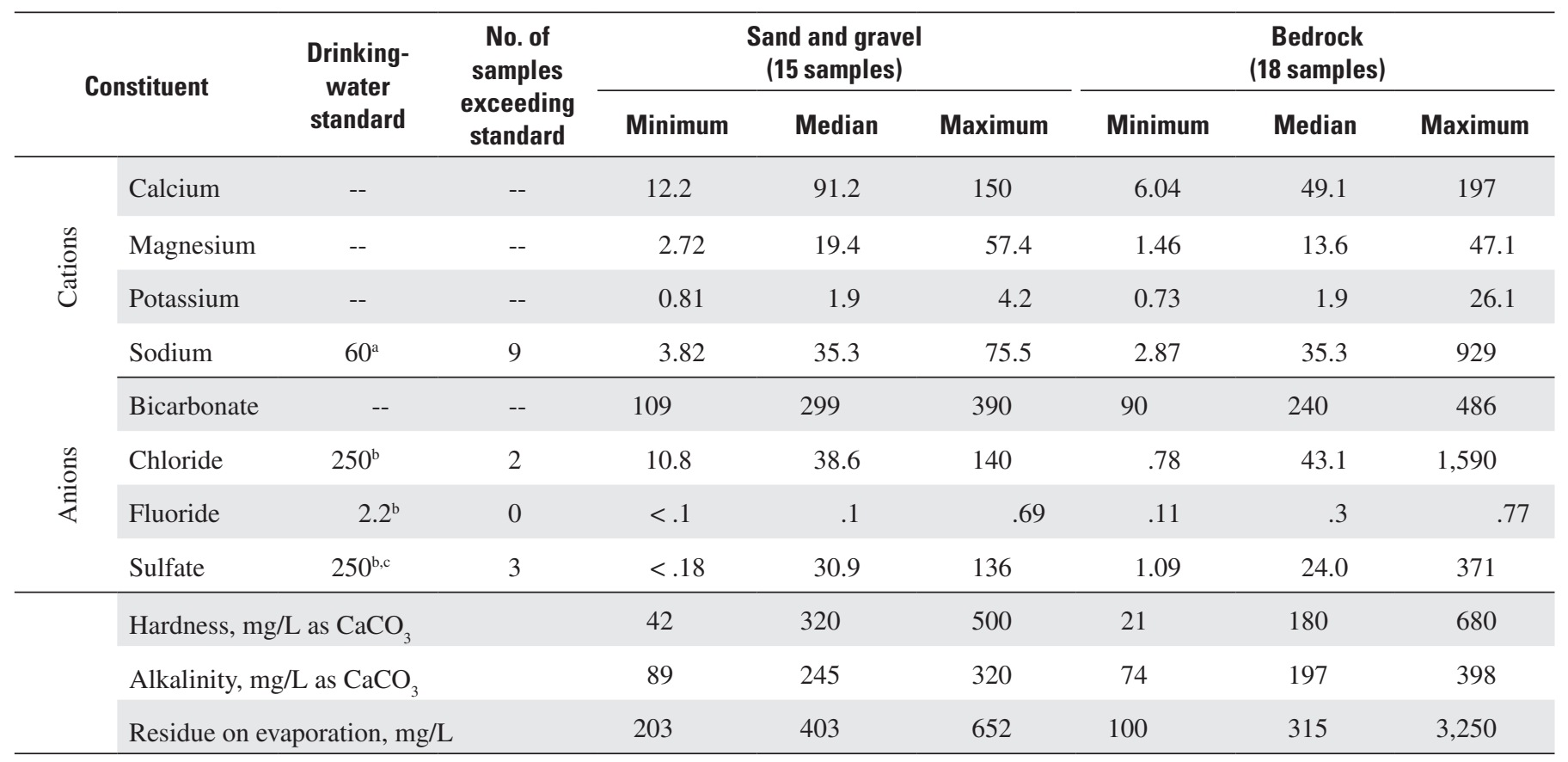

\footnotetext{
${ }^{a}$ USEPA Drinking Water Advisory Taste Threshold.

${ }^{\mathrm{b}}$ NYSDOH Maximum Contaminant Level.

${ }^{\mathrm{c}}$ USEPA Secondary Maximum Contaminant Level.
} 


\section{Nutrients and Organic Carbon}

Nitrate and ammonia were the predominant nutrients in the ground-water samples (table A5); nitrite and organic nitrogen concentrations were negligible in most samples. Nitrate plus nitrite concentrations ranged from less than 0.06 (the analytical detection limit) to $6.92 \mathrm{mg} / \mathrm{L}$ as nitrogen $(\mathrm{N})$, and ammonia concentrations ranged from less than $0.01 \mathrm{mo} 3 \mathrm{mg} / \mathrm{L}$ as $\mathrm{N}$. The nitrate MCL of $10 \mathrm{mg} / \mathrm{L}$ (as N) was not exceeded in any sample, and the concentrations in 20 of the 33 samples were below the detection limit (less than $0.06 \mathrm{mg} / \mathrm{L}$ ). Of the samples in which nitrate was detected, those from wells finished in sand and gravel had a higher median nitrate concentration $(2.40 \mathrm{mg} / \mathrm{L})$ than those from wells finished in bedrock $(0.18 \mathrm{mg} / \mathrm{L})$. Orthophosphate was detected in 30 of the 33 samples, but concentrations were typically low; the maximum concentration was $0.109 \mathrm{mg} / \mathrm{L}$ (as phosphorus). Total organic carbon was detected in 10 of the 33 samples; concentrations ranged from less than $1.0 \mathrm{mg} / \mathrm{L}$ (the analytical detection limit) to $3.6 \mathrm{mg} / \mathrm{L}$.

Table 3. Summary statistics for concentrations of nutrients and organic carbon in sand and gravel aquifers and bedrock aquifers in western New York, 2006.

[All samples represent filtered water except as noted; No., number; -- not applicable; <, less than; N, nitrogen; P, phosphorus]

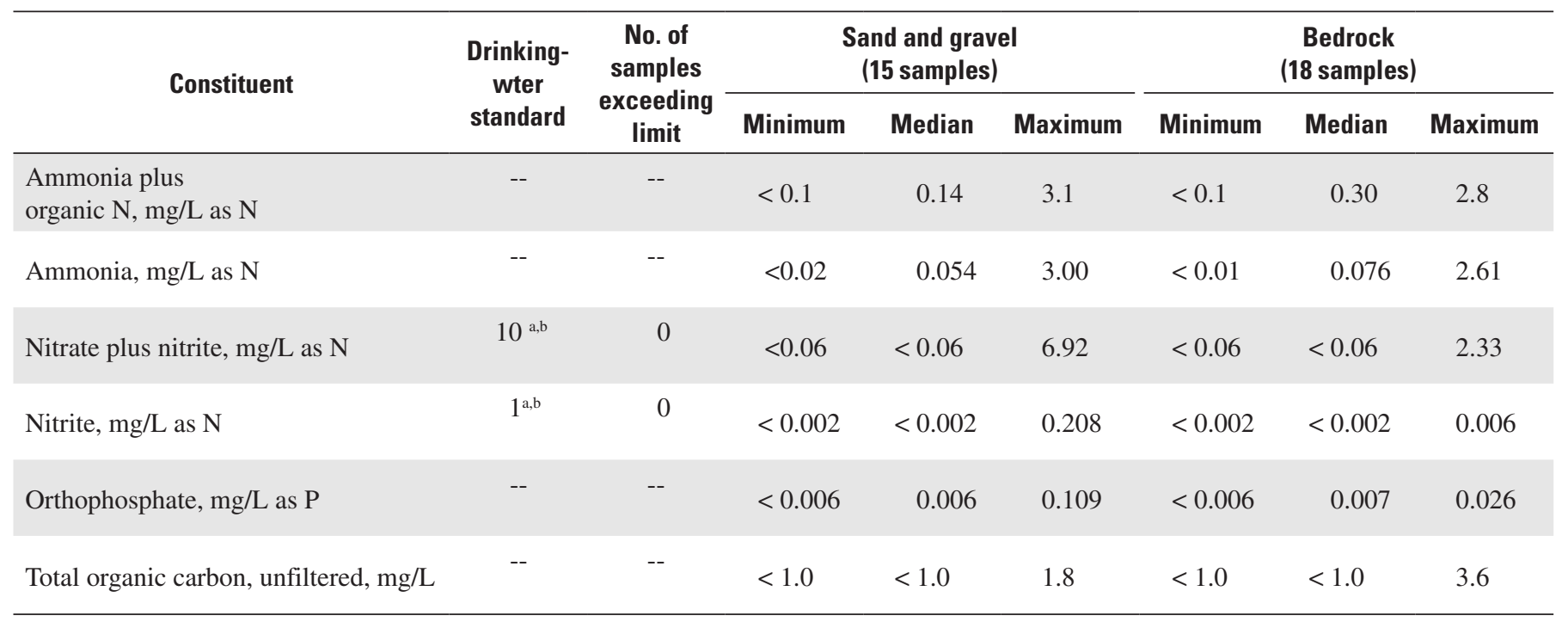

${ }^{a}$ USEPA Drinking Water Advisory Taste Threshold.

${ }^{\mathrm{b}}$ NYSDOH Maximum Contaminant Level.

\section{Trace Elements and Radon-222}

The most commonly detected trace elements were barium, boron, copper, lithium, nickel, and strontium, all of which were detected in every sample (tables 4 and A6). The elements detected in the highest concentrations were barium, boron, iron, lithium, manganese, and strontium. Barium concentrations ranged from 21.7 to 1,660 $\mu \mathrm{g} / \mathrm{L}$, but the $\mathrm{MCL}$ for barium $(2,000 \mu \mathrm{g} / \mathrm{L})$ was not exceeded. Boron concentrations ranged from 12 to $2,430 \mu \mathrm{g} / \mathrm{L}$, but MCLs have not been established for boron. Iron was detected in 29 of the 33 filtered samples at concentrations ranging from 3 to 3,220 $\mu \mathrm{g} / \mathrm{L}$, and the SMCL for iron $(300 \mu \mathrm{g} / \mathrm{L})$ was exceeded in 14 samples. Lithium concentrations ranged from 1.2 to $917 \mu \mathrm{g} / \mathrm{L}$, but MCLs have not been established for lithium. Manganese was detected in 29 of the 33 filtered samples at concentrations ranging from 0.5 to $696 \mu \mathrm{g} / \mathrm{L}$; the Federal SMCL for manganese $(50 \mu \mathrm{g} / \mathrm{L})$ was exceeded in 15 samples, and the New York State MCL (300 $\mu \mathrm{g} / \mathrm{L})$ was exceeded in 1 sample. Strontium concentrations ranged from 48.5 to 10,600 $\mu \mathrm{g} / \mathrm{L}$, but MCLs have not been established for strontium.

Aluminum was detected in 21 of the 33 samples, and the SMCL $(50 \mu \mathrm{g} / \mathrm{L})$ was exceeded in 1 sample. Arsenic was detected in 32 samples, and the MCL (10 $\mu \mathrm{g} / \mathrm{L})$ was exceeded in 2 samples. Lead was detected in 31 samples, and the MCL (15 $\mu \mathrm{g} / \mathrm{L})$ was exceeded once. 
Table 4. Summary statistics for concentrations of trace elements and radon-222 in sand and gravel aquifers and bedrock aquifers in western New York, 2006.

[All concentrations are in micrograms per liter except as noted. All samples unfiltered except as noted. pCi/L, picocuries per liter; No., number;

-- not applicable; <, less than; E, estimated]

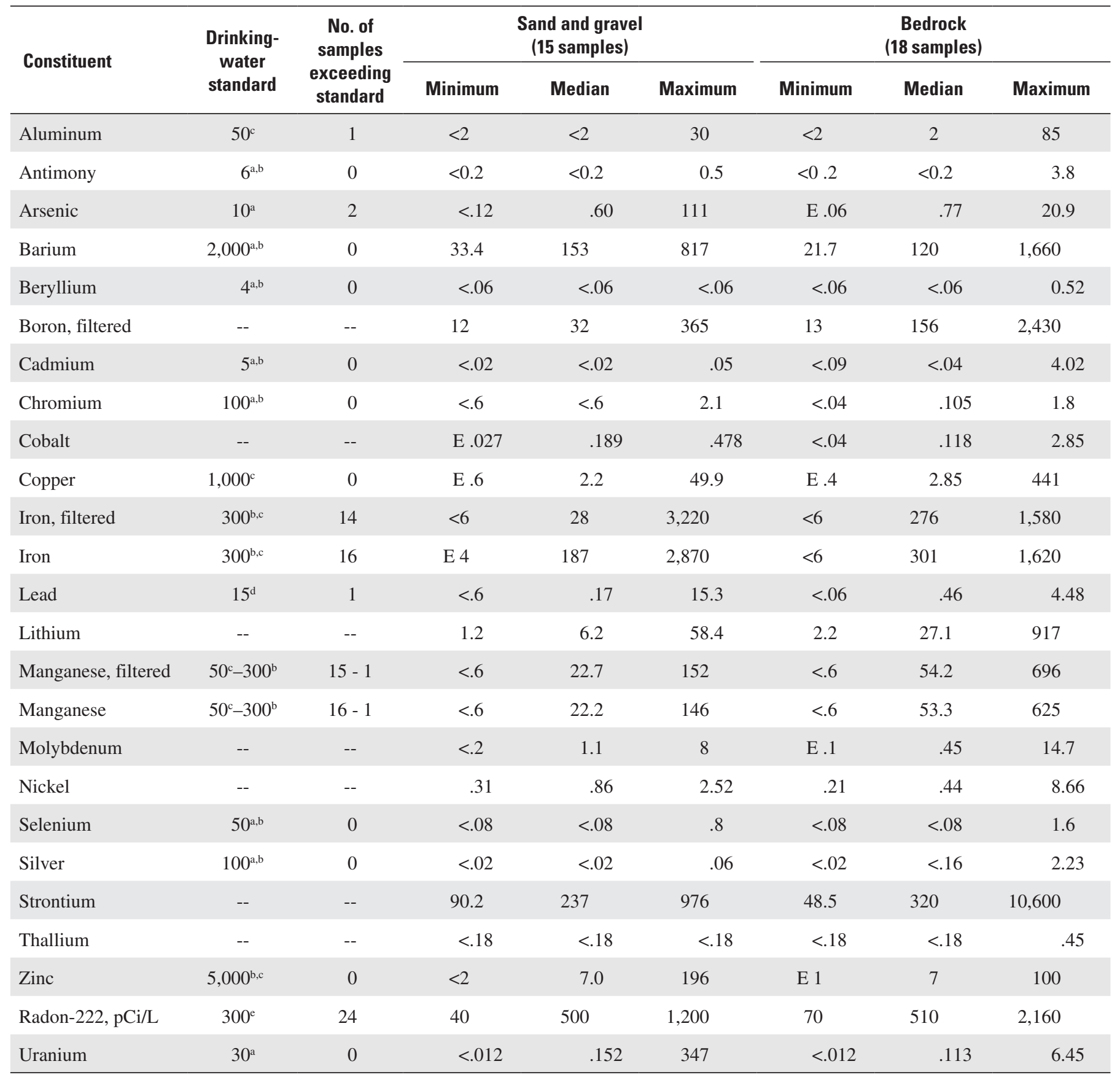

${ }^{a}$ USEPA Maximum Contaminant Level.

${ }^{\mathrm{b}}$ NYSDOH Maximum Contaminant Level.

c USEPA Secondary Maximum Contaminant Level.

${ }^{\mathrm{a}}$ USEPA Treatment Technique.

${ }^{\mathrm{e}}$ USEPA Proposed Maximum Contaminant Level. 
Uranium was detected in 26 samples, but none exceeded the MCL of $30 \mu \mathrm{g} / \mathrm{L}$. The MCLs for antimony (6 $\mu \mathrm{g} / \mathrm{L})$, beryllium $(4 \mu \mathrm{g} / \mathrm{L})$, cadmium $(5 \mu \mathrm{g} / \mathrm{L})$, chromium $(100 \mu \mathrm{g} / \mathrm{L})$, selenium $(50 \mu \mathrm{g} / \mathrm{L})$, and silver $(100 \mu \mathrm{g} / \mathrm{L})$ and the SMCLs for copper $(1,000 \mu \mathrm{g} / \mathrm{L})$ and zinc $(5,000 \mu \mathrm{g} / \mathrm{L})$ were not exceeded in any sample. Mercury was not detected in any sample (table A2).

Radon-222 was detected in every sample (table A6), and concentrations ranged from 40 to 2,160 pCi/L. The proposed MCL of $300 \mathrm{pCi} / \mathrm{L}$ for radon-222 in drinking water was exceeded in 24 samples, but the proposed AMCL of 4,000 pCi/L was not exceeded. The AMCL is the proposed allowable concentration of radon in raw-water samples where programs have been implemented to address the health risks of radon in indoor air, but none of the 33 well sites sampled in this study had such implementation. The proposed MCL and AMCL for radon are under review and have not been adopted (U.S. Environmental Protection Agency, 2004; 2006).

\section{Pesticides}

Eighteen pesticides (including 9 pesticide degradates) were detected in water from 14 of the 33 wells (table A7), but none of the concentrations exceeded MCLs. Eight of the samples containing pesticides were from sand and gravel aquifers, and six were from bedrock aquifers. Caffeine, which is not a pesticide and can be an indicator of human wastes, is included in table A7 because it is measured as part of the pesticide analyses and was detected at a trace level in one sample. The pesticide compounds that were detected most frequently were herbicide degradation products-CIAT (2-chloro-4-isopropylamino6-amino-s-triazine, also called deethylatrazine, a degradation product of atrazine), alachlor ESA (a degradation product of alachlor), and metolachlor ESA and OA (degradation products of metolachlor). CIAT was detected in six samples; the maximum concentration was $0.019 \mu \mathrm{g} / \mathrm{L}$. Metolachlor and siduron were detected in three samples; their maximum concentrations were $0.400 \mu \mathrm{g} / \mathrm{L}$ and $0.01 \mu \mathrm{g} / \mathrm{L}$, respectively. Atrazine was detected in two samples; the maximum concentration was $0.104 \mu \mathrm{g} / \mathrm{L}$. Alachlor was detected in one sample, at a concentration of $1.03 \mu \mathrm{g} / \mathrm{L}$. No Federal MCLs currently have been established for pesticide degradation products, and no pesticide concentration exceeded the New York State MCL of $50 \mu \mathrm{g} / \mathrm{L}$. These trace-level detections of pesticides are similar to those reported by Eckhardt and others (2001), Phillips and others (1999), and Eckhardt and Stackelberg (1995) from studies of pesticides in ground water throughout New York State.

\section{Volatile Organic Compounds and Phenolic Compounds}

Fourteen VOCs were detected in 12 samples (table A8), but none of the concentrations exceeded MCLs. Phenolic compounds, which are semivolatile, were detected in one sample at a concentration of $8 \mu \mathrm{g} / \mathrm{L}$. Toluene was detected in four samples; the maximum concentration was $0.9 \mu \mathrm{g} / \mathrm{L}$. Trichloromethane was detected in three samples, and tribromomethane and dibromochloromethane were each detected in one sample; these compounds are called trihalomethanes and are typically formed as disinfection by-products that result from chlorination of water. Xylene compounds were detected in three samples; the maximum concentration was $29.8 \mu \mathrm{g} / \mathrm{L}$ for the meta plus para isomers. Methyl tert-butyl ether (MTBE), a gasoline additive that can infiltrate into ground water from leaking fuel tanks, was detected in two samples; the maximum concentration was $1.3 \mu \mathrm{g} / \mathrm{L}$. The New York State MCL for MTBE is $10 \mu \mathrm{g} / \mathrm{L}$, which was not exceeded. No Federal MCL has been established for MTBE, although the USEPA has suggested a limit of 20 to $40 \mu \mathrm{g} / \mathrm{L}$ on the basis of taste and odor of drinking water (U.S. Environmental Protection Agency, 2006).

\section{Bacteria}

All samples were analyzed for total coliform, fecal coliform, Escherichia coli (E. coli), and heterotrophic bacteria. Total coliform was detected in 12 samples, and E. coli in 2 samples (table A9). These bacteria were detected in four samples from sand and gravel aquifers and in nine samples from bedrock aquifers; eight of these samples were from private residential wells, and one was from a production well (E 1084, fig. 1), which taps a sand and gravel aquifer. Any detection of these bacteria is considered a violation of New York State health regulations, and well owners were notified of positive results upon receipt of laboratory results. The raw-water samples collected in this study were collected prior to disinfection treatments, and most production wells have chlorination systems that eliminate potential contamination by bacteria before the water is distributed to consumers; however, private residential wells generally lack a chlorination system.

Heterotrophic plate counts (HPCs) ranged from less than 2 to greater than 738 colony-forming units per milliliter (CFU/mL). The USEPA MCL for HPC is $500 \mathrm{CFU} / \mathrm{mL}$, and four samples exceeded this limit. 


\section{Summary}

In 2001, the USGS, in cooperation with the NYSDEC and the USEPA, began an assessment of ground-water quality in river basins throughout New York State. As a part of this assessment, water samples were collected from 33 production wells and private residential wells throughout western New York from August through December 2006 and were analyzed for 5 physical properties and 219 constituents that included inorganic major ions, nutrients, organic carbon, trace elements, radon-222, VOCs, phenolic compounds, pesticides, and bacteria. The quality of the sampled ground water was generally acceptable, except where concentrations of certain constituents exceeded recommended MCLs, SMCLs, or HAs set by the USEPA and NYSDOH. Of the 78 constituents that were detected, 8 exceeded Federal and State MCLs, SMCLs, or HAs at specific wells; 3 types of bacteria also were detected in concentrations that exceeded MCLs at some wells.

The cations that were detected in the highest concentrations were calcium, magnesium, and sodium; the anions that were detected in the highest concentrations were bicarbonate, chloride, and sulfate. The predominant nutrients were nitrate and ammonia; no sample exceeded the MCL (10 mg/L as N) for nitrate. The HA for sodium in drinking water $(60 \mathrm{mg} / \mathrm{L}) \mathrm{was}$ exceeded in 9 of the 33 samples; the sulfate SMCL (250 mg/L) was exceeded in 3 samples; and the chloride SMCL (250 mg/L) was exceeded in 2 samples.

The trace elements detected in the highest concentrations were barium, boron, iron, lithium, manganese, and strontium, but of these, only dissolved iron, manganese, and aluminum concentrations exceeded SMCLs. Iron was detected in 29 of the 33 filtered samples at concentrations ranging from 3 to 3,220 $\mu \mathrm{g} / \mathrm{L}$, and the SMCL for iron $(300 \mu \mathrm{g} / \mathrm{L})$ was exceeded in 14 samples. Manganese was detected in 29 filtered samples at concentrations ranging from 0.5 to 696 $\mu \mathrm{g} / \mathrm{L}$; the USEPA SMCL for manganese $(50 \mu \mathrm{g} / \mathrm{L})$ was exceeded in 15 samples, and the New York State MCL (300 $\mu \mathrm{g} / \mathrm{L})$ was exceeded in 1 sample. Aluminum was detected in 21 samples, and the SMCL (50 $\mu \mathrm{g} / \mathrm{L})$ was exceeded once. Arsenic was detected in 32 samples, and the MCL for arsenic (10 $\mu \mathrm{g} / \mathrm{L})$ was exceeded in 2 samples. Lead was detected in 32 samples, and the MCL (15 $\mu \mathrm{g} / \mathrm{L})$ was exceeded once. Radon-222 was detected in every sample; the proposed Federal MCL for radon-222 in drinking water (300 pCi/L) was exceeded in 24 samples, but the proposed AMCL (4,000 pCi/L) was not exceeded in any sample.

Eighteen pesticides, including 9 pesticide degradates, were detected in water from 14 of the 33 wells; most of the concentrations were at or near the detection limits, and no concentration exceeded an MCL. Eight of the samples containing pesticides were from sand and gravel aquifers, and six were from bedrock aquifers. Caffeine was detected at a trace level in one sample. Fourteen VOCs were detected in 12 samples, but no concentration exceeded an MCL. Any detection of total coliform or fecal coliform bacteria is considered a violation of New York State MCLs; in this study, total coliform was detected in 12 samples, and E. coli was detected in 2 samples. Heterotrophic plate counts exceeded the MCL of $500 \mathrm{CFU} / \mathrm{mL}$ in four samples.

\section{References Cited}

Anderson, R.M., Beer, K.M., Buckwalter, T.F., Clark, M.E., McAuley, S.D., Sams, J.I., and Williams, D.R., 2000, Water quality in the Allegheny and Monongahela River basins, Pennsylvania, West Virginia, New York, and Maryland, 1996-98: U.S. Geological Survey Circular 1202, 32 p.

Brett, C.E., Tepper, D.H., Goodman, W.M., LoDuca, S.T., and Eckert, Bea-Yeh, 1995, Revised stratigraphy and correlations of the Niagran Provincial Series (Medina, Clinton, and Lockport Groups) in the type area of western New York: U.S. Geological Survey Bulletin 2086, 66 p.

Broughton, J.G., Fisher, D.W., Isachsen, Y.W., Rickard, L.V., and Offield, T.W., 1962, The geology of New York State: Albany, New York State Museum-Geological Survey, Map and Chart Series no. 5, 5 sheets, scale 1:250,000.

Cadwell, D.H., and Muller, E.H., 1986, Surficial geologic map of New York: Albany, New York State Museum-Geological Survey, Map and Chart Series no. 40, 5 sheets, scale 1:250,000, digital compilation by Beckie Ugolini, 1998, from New York State Geological Survey 90-meter Digital Elevation Model.

Coates, D.R., 1966, Glaciated Appalachian Plateau-Till shadows on hills: Science, v. 152, p. 1617-1619.

Cosner, O.J., 1984, Atlas of four selected aquifers in New York: Washington, D.C., U.S. Environmental Protection Agency Report 68-01-6389, 102 p.

Crain, L.J., 1966, Ground-water resources of the Jamestown area, New York, with emphasis on the hydrology of the major stream valleys: New York State Water Resources Commission Bulletin 58, 167 p. 
Eckhardt, D.A., Hetcher, K.K., Phillips, P.J., and Miller, T.S., 2001, Pesticides and their metabolites in community watersupply wells of central and western New York, August 1999: U.S. Geological Survey Water-Resources Investigations Report 00-4128, 12 p.

Eckhardt, D.A., Reddy, J.E., and Tamulonis, K.L., 2007, Ground-water quality in the Genesee River basin, New York, 2005-06: U.S. Geological Survey Open-File Report 2007-1093, 26 p.

Eckhardt, D.A. and Stackelberg, P.E., 1995, Relation of ground-water quality to land use of Long Island, New York: Ground Water, v. 33, no. 6, p. 1019-1033.

Erie County, 1985, Erie County ground water management program: Buffalo, N.Y., Department of Environment and Planning, $22 \mathrm{p}$.

Fairchild, H.L., 1928, Geologic story of the Genesee Valley and drainage history of western New York: Rochester, Gas and Electric News, July 1926 to July 1928.

Frimpter, M.H., 1974, Ground-water resources, Allegheny River basin and part of the Lake Erie basin, New York: New York State Department of Environmental Conservation Basin Planning Report ARB-2, 98 p.

Frimpter, M.H., 1986, Surficial geology and ground-water availability in the Allegheny River basin and part of the Lake Erie basin, New York: U.S. Geological Survey Water-Resources Investigations Report 86-4041, 2 sheets.

Furlong, E.T., Anderson, B.D., Werner, S.L., Soliven, P.P., Coffey, L.J., and Burkhardt, M.R., 2001, Methods of analysis by the U.S. Geological Survey National Water Quality Laboratory-Determination of pesticides in water by graphitized carbonbased solid-phase extraction and high-performance liquid chromatography/mass spectrometry: U.S. Geological Survey Water-Resources Investigations Report 01-4134, 73 p.

Gilbert, B.K., and Kammerer, J.C., 1971, Hydrology of the Genesee River basin, New York and Pennsylvania: U.S. Geological Survey Hydrologic Investigations Atlas HA-368, 4 sheets.

Hem, J.D., 1985, Study and interpretation of the chemical characteristics of natural water (3RD ed.): U.S. Geological Survey Water Supply Paper 2254, 264 p.

Hetcher-Aguila, K.K., 2004, Ground-water quality in the Chemung River basin, New York, 2003: U.S. Geological Survey Open-File Report 04-1329, 19 p.

Hetcher-Aguila, K.K., and Eckhardt, D.A., 2006, Ground-water quality in the upper Susquehanna River basin, New York, 2004-05: U.S. Geological Survey Open-File Report 06-1161, 20 p.

Johnston, R.H., 1964, Ground water in the Niagara Falls area, New York, with emphasis on the water-bearing characteristics of the bedrock: Albany, N.Y., New York State Water Resources Commission Bulletin GW-53, 93 p.

Kappel, W.M., and Miller, T.S., 1996, Geology, hydrology, and ground-water flow near the Akron municipal well, Erie County, New York: U.S. Geological Survey Water-Resources Investigations Report 96-4193, 21 p.

Koszalka, E.J., Paschal, J.E., Jr., Miller, T.S., and Duran, P.B., 1985, Preliminary evaluation of chemical migration to groundwater and the Niagara River from selected waste-disposal sites: Troy, N.Y., U.S. Geological Survey administrative report, 425 p., 3 pls.

La Sala, A.M., 1968, Ground-water resources of the Erie-Niagara basin, New York: New York State Water Resources Commission Basin Planning Report ENB-3, 114 p.

Lee, E.A., and Strahan, A.P., 2003, Determination of acetamide herbicides and their degradation products in water using online solid-phase extraction and liquid chromatography/mass spectrometry: U.S. Geological Survey Open-File Report 03-173, $17 \mathrm{p}$.

Meyer, M.T., Mills, M.S., and Thurman, E.M., 1993, Automated solid-phase extraction of herbicides from water for gas chromatographic-mass spectrometric analysis: Journal of Chromatography, v. 629, p. 55-59.

Miller, T.S., 1988, Unconsolidated aquifers in upstate New York-Finger Lakes sheet: U.S. Geological Survey Water-Resources Investigations Report 87-4122, 1 sheet, scale 1:250,000. 
Miller, T.S., and Staubitz, W.W., 1985, Hydrogeologic appraisal of five selected aquifers in Erie County, New York: U.S. Geological Survey Water-Resources Investigations Report 84-4334, 89 p.

Moore, R.B., and Staubitz, W.W., 1984, Distribution and source of barium in ground-water at Cattaraugus Indian Reservation, southwestern New York: U.S. Geological Survey Water-Resources Investigations Report 84-4129, 17 p.

New York State Department of Health, 2005, Drinking water protection program: Troy, N.Y., Bureau of Public Water Supply Protection.

New York State Department of Health, 2006, Drinking water protection program: Albany, N.Y., accessed January 25, 2007, at http://www.health.state.ny.us/nysdoh/water/part5/tables.htm

Nystrom, E.A., 2006, Ground-water quality in the Lake Champlain basin, New York, 2004: U.S. Geological Survey Open-File Report 06-1088, 21 p.

Nystrom, E.A., 2007a, Ground-water quality in the Delaware River basin, New York, 2001 \& 2005-2006: U.S. Geological Survey Open-File Report 2007-1098, 37 p.

Nystrom, E.A., 2007b, Ground-water quality in the St. Lawrence River basin, New York, 2005-2006: U.S. Geological Survey Open-File Report 2007-1066, 33 p.

Nystrom, E.A., 2008, Ground-water quality in the Mohawk River basin, New York, 2006: U.S. Geological Survey Open-File Report 2008-1086, 33 p.

Phillips, P.J., Eckhardt, D.A., Terracciano, S.A., and Rosenmann, L.R., 1999, Pesticides and their metabolites in wells of Suffolk County, New York, 1998: U.S. Geological Survey Water-Resources Investigations Report 99-4095, 12 p.

Randall, A.D., 2001, Hydrogeologic framework of stratified-drift aquifers in the glaciated Northeastern United States: U.S. Geological Survey Professional Paper 1415-B, 179 p.

Sandstrom, M.W., Stroppel, M.E., Foreman, W.T., and Schroeder, M.P., 2001, Methods of analysis by the U.S. Geological Survey National Water Quality Laboratory-Determination of moderate-use pesticides and selected degradates in water by C-18 solid-phase extraction and gas chromatography/mass spectrometry: U.S. Geological Survey Water-Resources Investigations Report 01-4098, 70 p.

Shelton, L.R., 1994, Field guide for collecting and processing stream-water samples for the National Water-Quality Assessment Program: U.S. Geological Survey Open-File Report 94-455, 42 p.

Staubitz, W.W., and Miller, T.S., 1987, Geology and hydrology of the Onondaga aquifer in eastern Erie County, New York, with emphasis on ground-water-level declines since 1982: U.S. Geological Survey Water-Resources Investigations Report 86-4317, 44 p.

U.S. Department of Commerce, 2000, Redistricting Census 2000: Washington D.C., Bureau of the Census Geography Division, accessed January 2007, at http://www.census.gov/geo/www/index.html

U.S. Environmental Protection Agency, 1997, Guidelines for preparation of the comprehensive state water quality assessments (305(b) reports and electronic updates: Washington, D.C., Office of Water, EPA 841-B-97-002A and EPA 841-B-97-002B, PL 95-217.

U.S. Environmental Protection Agency, 2002, Drinking-water advisory-Consumer acceptability advice and health effects analysis on sodium: Washington, D.C., Office of Water, EPA 822-R-02-032, 34 p.

U.S. Environmental Protection Agency, 2004, Proposed radon in drinking water rule: Washington, D.C., Office of Water, accessed January 2007, at http://www.epa.gov/safewater/radon/proposal.html

U.S. Environmental Protection Agency, 2006, Drinking water standards and health advisories: Washington, D.C., Office of Water, EPA 822-R-06-013, Oct. 1996, 12 p.

U.S. Geological Survey, 2006, Field methods: accessed January 2007, at http://water.usgs.gov/owq/Fieldprocedures.html

U.S. Geological Survey, 2007, National Water Quality Laboratory: accessed January 2007, at http://nwql.usgs.gov 
Yager, R.M., Miller, T.S., and Thayer, John, 1997, Delineation of areas contributing recharge to municipal wells in three selected confined-glacial aquifers in Erie County, New York: U.S. Geological Survey Water-Resources Investigations Report 96-4229, $40 \mathrm{p}$.

Zaugg, S.D., Sandstrom, M.W., Smith, S.G., and Fehlberg, K.M., 1995, Methods of analysis by the U.S. Geological Survey National Water Quality Laboratory-Determination of pesticides in water by C-18 solid-phase extraction and capillarycolumn gas chromatography with selective-ion monitoring: U.S. Geological Survey Open-File Report 95-181, 49 p. 

Appendix 
Table A1. Information on wells sampled in western New York study area, 2006.

[Well locations are shown in figure 1. --, information not available]

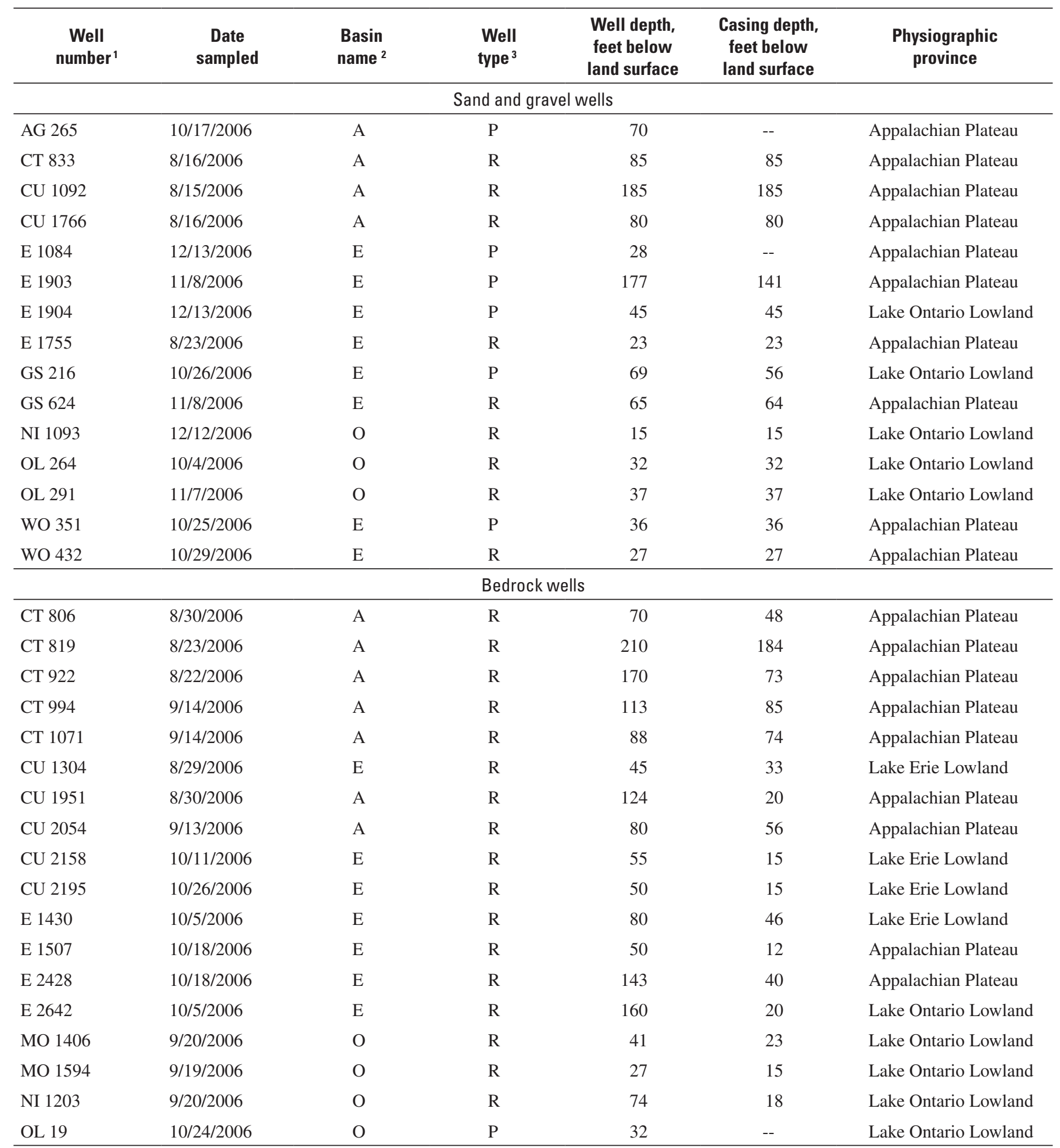

${ }^{1}$ Two-letter prefix denotes county: AG, Allegany; CT, Cattaraugus; CU, Chatauqua; E, Erie; GS, Genesee; MO, Monroe; NI, Niagara; OL, Orleans; WO, Wyoming; number is local well-identification number assigned by U.S. Geological Survey.

${ }^{2}$ A, Allegheny River; E, Lake Erie and Niagara River; O, Western Lake Ontario.

${ }^{3}$ P, Production well; R, Residential well. 
Table A2. Compounds for which ground-water samples from western New York were analyzed but not detected, 2006.

\begin{tabular}{|c|c|c|}
\hline $\begin{array}{c}\text { USGS } \\
\text { parameter } \\
\text { code } \\
\end{array}$ & Constituent & $\begin{array}{c}\begin{array}{c}\text { Laboratory reporting level, } \\
\text { micrograms per liter } \\
(\mu \mathrm{g} / \mathrm{L})\end{array} \\
\end{array}$ \\
\hline \multicolumn{3}{|c|}{ Trace elements in unfiltered water } \\
\hline 71900 & Mercury & $0.190-0.200$ \\
\hline \multicolumn{3}{|c|}{ Pesticides in filtered water } \\
\hline 50470 & 2,4-D methyl ester & 0.016 \\
\hline 39732 & 2,4-D & 0.04 \\
\hline 82660 & 2,6-Diethylaniline & 0.006 \\
\hline 50355 & $\begin{array}{l}\text { 2-Hydroxy-4-isopropyl-amino-6-ethyl- } \\
\text { amino-s-triazine }\end{array}$ & $0.032-0.080$ \\
\hline 49260 & Acetochlor & 0.006 \\
\hline 61029 & Acetochlor ethanesulfonic acid & 0.02 \\
\hline 61030 & Acetochlor oxanilic acid & 0.02 \\
\hline 62847 & Acetochlor sulfynilacetic acid & 0.02 \\
\hline 49315 & Acifluorfen & $0.028-0.060$ \\
\hline 62849 & $\begin{array}{l}\text { Alachlor ethanesulfonic acid second } \\
\text { amide }\end{array}$ & 0.02 \\
\hline 61031 & Alachlor oxanilic acid & 0.02 \\
\hline 63781 & Alachlor second amide & 0.02 \\
\hline 62848 & Alachlor sulfynilacetic acid & 0.02 \\
\hline 49313 & Aldicarb sulfone & $0.02-0.08$ \\
\hline 49314 & Aldicarb sulfoxide & $0.040-0.100$ \\
\hline 49312 & Aldicarb & $0.04-0.15$ \\
\hline 34253 & alpha-HCH & 0.005 \\
\hline 82686 & Azinphos-methyl & $0.050-0.080$ \\
\hline 50299 & Bendiocarb & $0.04-0.08$ \\
\hline 50300 & Benomyl & $0.020-0.022$ \\
\hline 61693 & Bensulfuron & $0.02-0.06$ \\
\hline 38711 & Bentazon & 0.02 \\
\hline 04029 & Bromacil & $0.02-0.04$ \\
\hline 49311 & Bromoxynil & $0.04-0.12$ \\
\hline 04028 & Butylate & 0.004 \\
\hline 49310 & Carbaryl & 0.02 \\
\hline 82680 & Carbaryl & $0.041-0.060$ \\
\hline 49309 & Carbofuran & $0.016-0.060$ \\
\hline 82674 & Carbofuran & 0.020 \\
\hline 61188 & Chloramben methyl ester & $0.02-0.10$ \\
\hline 50306 & Chlorimuron & $0.032-0.080$ \\
\hline 04039 & Chlorodiamino-s-triazine & $0.04-0.12$ \\
\hline 38933 & Chlorpyrifos & 0.005 \\
\hline 82687 & cis-Permethrin & $0.006-0.010$ \\
\hline
\end{tabular}


Table A2. Compounds for which ground-water samples from western New York were analyzed but not detected, 2006.-Continued

\begin{tabular}{|c|c|c|}
\hline $\begin{array}{l}\text { USGS } \\
\text { parameter } \\
\text { code }\end{array}$ & Constituent & $\begin{array}{l}\text { Laboratory reporting level, } \\
\text { micrograms per liter } \\
(\mu \mathrm{g} / \mathrm{L})\end{array}$ \\
\hline \multicolumn{3}{|c|}{ Pesticides in filtered water } \\
\hline 49305 & Clopyralid & $0.06-0.07$ \\
\hline 04041 & Cyanazine & 0.018 \\
\hline 04031 & Cycloate & $0.01-0.06$ \\
\hline 49304 & Dacthal monoacid & $0.02-0.03$ \\
\hline 82682 & DCPA & 0.003 \\
\hline 63778 & Dechloroacetochlor & 0.02 \\
\hline 63777 & Dechloroalachlor & 0.02 \\
\hline 63779 & Dechlorodimethenamid & 0.02 \\
\hline 63780 & Dechlorometolachlor & 0.02 \\
\hline 62170 & Desulfinyl fipronil & 0.012 \\
\hline 39572 & Diazinon & $0.005-0.026$ \\
\hline 38442 & Dicamba & $0.04-0.08$ \\
\hline 49302 & Dichlorprop & $0.03-0.04$ \\
\hline 39381 & Dieldrin & 0.009 \\
\hline 61951 & Dimethenamid ethanesulfonic acid & 0.02 \\
\hline 62482 & Dimethenamid oxanilic acid & 0.02 \\
\hline 61588 & Dimethenamid & 0.02 \\
\hline 49301 & Dinoseb & 0.04 \\
\hline 04033 & Diphenamid & $0.01-0.04$ \\
\hline 82677 & Disulfoton & 0.02 \\
\hline 49300 & Diuron & $0.02-0.04$ \\
\hline 82668 & EPTC & 0.004 \\
\hline 82663 & Ethalfluralin & 0.009 \\
\hline 82672 & Ethoprop & 0.012 \\
\hline 49297 & Fenuron & $0.04-0.10$ \\
\hline 62169 & Desulfinylfipronil amide & 0.029 \\
\hline 62167 & Fipronil sulfide & 0.013 \\
\hline 62168 & Fipronil sulfone & 0.024 \\
\hline 62166 & Fipronil & 0.016 \\
\hline 61952 & Flufenacet ethanesulfonic acid & 0.02 \\
\hline 62483 & Flufenacet oxanilic acid & 0.02 \\
\hline 62481 & Flufenacet & 0.02 \\
\hline 61694 & Flumetsulam & $0.04-0.06$ \\
\hline 38811 & Fluometuron & $0.02-0.04$ \\
\hline 04095 & Fonofos & $0.005-0.006$ \\
\hline 63784 & Hydroxyacetochlor & 0.02 \\
\hline 63785 & Hydroxymetolachlor & 0.02 \\
\hline 64045 & Hydroxydimethenamid & 0.02 \\
\hline
\end{tabular}


Table A2. Compounds for which ground-water samples from western New York were analyzed but not detected, 2006.-Continued

\begin{tabular}{|c|c|c|}
\hline $\begin{array}{l}\text { USGS } \\
\text { parameter } \\
\text { code }\end{array}$ & Constituent & $\begin{array}{c}\text { Laboratory reporting level, } \\
\text { micrograms per liter } \\
(\mu \mathrm{g} / \mathrm{L})\end{array}$ \\
\hline \multicolumn{3}{|c|}{ Pesticides in filtered water } \\
\hline 50356 & Imazaquin & 0.04 \\
\hline 50407 & Imazepyr & 0.04 \\
\hline 61695 & Imidacloprid & $0.020-0.060$ \\
\hline 39341 & Lindane & 0.004 \\
\hline 38482 & MCPA & $0.06-0.07$ \\
\hline 38487 & МCPB & $0.10-0.20$ \\
\hline 50359 & Metalaxyl & $0.03-0.04$ \\
\hline 38501 & Methiocarb & $0.034-0.040$ \\
\hline 49296 & Methomyl & $0.060-0.070$ \\
\hline 82667 & Methyl parathion & 0.015 \\
\hline 82630 & Metribuzin & 0.028 \\
\hline 61697 & Metsulfuron & $0.07-0.14$ \\
\hline 82671 & Molinate & 0.003 \\
\hline 61692 & $N$-(4-Chlorophenyl)- $N^{\prime}$-methylurea & $0.04-0.06$ \\
\hline 82684 & Napropamide & $0.007 \quad 0.018$ \\
\hline 49294 & Neburon & $0.01-0.02$ \\
\hline 50364 & Nicosulfuron & $0.04-0.10$ \\
\hline 49293 & Norflurazon & $0.02-0.04$ \\
\hline 49292 & Oryzalin & $0.02-0.04$ \\
\hline 38866 & Oxamyl & $0.04-0.05$ \\
\hline 34653 & $p, p^{\prime}-\mathrm{DDE}$ & 0.003 \\
\hline 39542 & Parathion & 0.010 \\
\hline 82669 & Pebulate & 0.004 \\
\hline 82683 & Pendimethalin & 0.022 \\
\hline 82664 & Phorate & $0.011-0.055$ \\
\hline 49291 & Picloram & $0.03-0.12$ \\
\hline 04037 & Prometon & 0.01 \\
\hline 82676 & Propyzamide & 0.004 \\
\hline 62766 & Propachlor ethanesulfonic acid & 0.05 \\
\hline 62767 & Propachlor oxanilic acid & 0.02 \\
\hline 82679 & Propanil & 0.011 \\
\hline 82685 & Propargite & 0.02 \\
\hline 49236 & Propham & $0.030-0.060$ \\
\hline 50471 & Propiconazole & $0.01-0.060$ \\
\hline 38538 & Propoxur & $0.008-0.040$ \\
\hline 50337 & Sulfometuron & $0.060-0.090$ \\
\hline 82670 & Tebuthiuron & $0.026-0.040$ \\
\hline 82665 & Terbacil & $0.034-0.040$ \\
\hline
\end{tabular}


Table A2. Compounds for which ground-water samples from western New York were analyzed but not detected, 2006.-Continued

\begin{tabular}{|c|c|c|}
\hline $\begin{array}{l}\text { USGS } \\
\text { parameter } \\
\text { code }\end{array}$ & Constituent & $\begin{array}{l}\text { Laboratory reporting level, } \\
\text { micrograms per liter } \\
(\mu \mathrm{g} / \mathrm{L})\end{array}$ \\
\hline \multicolumn{3}{|c|}{ Pesticides in filtered water } \\
\hline 04032 & Terbacil & $0.026-0.040$ \\
\hline 82675 & Terbufos & $0.01-0.02$ \\
\hline 82681 & Thiobencarb & 0.010 \\
\hline 82678 & Triallate & 0.006 \\
\hline 49235 & Triclopyr & $0.03-0.04$ \\
\hline 82661 & Trifluralin & $0.006-0.009$ \\
\hline \multicolumn{3}{|c|}{ Volatile organic compounds, in unfiltered water } \\
\hline 77652 & 1,1,2-Trichloro-1,2,2-trifluoroethane & 0.1 \\
\hline 34501 & 1,1-Dichloroethene & 0.1 \\
\hline 34536 & 1,2-Dichlorobenzene & 0.1 \\
\hline 32103 & 1,2-Dichloroethane & 0.2 \\
\hline 34541 & 1,2-Dichloropropane & 0.1 \\
\hline 34566 & 1,3-Dichlorobenzene & 0.1 \\
\hline 34571 & 1,4-Dichlorobenzene & 0.1 \\
\hline 34030 & Benzene & 0.1 \\
\hline 32101 & Bromodichloromethane & 0.1 \\
\hline 34301 & Chlorobenzene & 0.1 \\
\hline 77093 & cis-1,2-Dichloroethene & 0.1 \\
\hline 81576 & Diethyl ether & 0.2 \\
\hline 81577 & Diisopropyl ether & 0.2 \\
\hline 50005 & Methyl tert-pentyl ether & 0.2 \\
\hline 77128 & Styrene & $0.1-0.3$ \\
\hline 50004 & tert-Butyl ethyl ether & 0.1 \\
\hline 32102 & Tetrachloromethane & 0.2 \\
\hline 34546 & trans-1,2-Dichloroethene & 0.1 \\
\hline 34488 & Trichlorofluoromethane & 0.2 \\
\hline 39175 & Vinyl Choride & 0.2 \\
\hline
\end{tabular}


Table A3. Physical properties of ground-water samples from western New York study area, 2006.

[Well locations are shown in figure $1 . \mathrm{mg} / \mathrm{L}$, milligrams per liter; $<$, less than; $\mu \mathrm{S} / \mathrm{cm}$, microsiemens per centimeter at $25^{\circ} \mathrm{C}$; $(00080), \mathrm{National}$ Water Information System (NWIS) parameter code; --, no data]

\begin{tabular}{|c|c|c|c|c|c|}
\hline $\begin{array}{c}\text { Well } \\
\text { number }{ }^{1}\end{array}$ & $\begin{array}{l}\text { Water color, } \\
\text { filtered, } \\
\text { platinum } \\
\text { cobalt units } \\
(\mathbf{0 0 0 8 0 )}\end{array}$ & $\begin{array}{c}\text { Dissolved- } \\
\text { oxygen } \\
\text { concentration, } \\
\text { field, } \mathrm{mg} / \mathrm{L} \\
(00300)\end{array}$ & $\begin{array}{c}\text { pH, field, } \\
\text { standard } \\
\text { units } \\
(00400)\end{array}$ & $\begin{array}{c}\text { Specific } \\
\text { conductance, } \\
\text { field, } \mu \mathrm{S} / \mathrm{cm} \\
(00095)\end{array}$ & $\begin{array}{c}\text { Water } \\
\text { temperature, } \\
\text { degrees Celsius } \\
(00010)\end{array}$ \\
\hline \multicolumn{6}{|c|}{ Sand and gravel wells } \\
\hline AG 265 & 5 & 3.0 & 6.4 & 495 & 12.7 \\
\hline CT 833 & $<1$ & 6.3 & 7.4 & 369 & 9.6 \\
\hline CU 1092 & 12 & $<0.3$ & 7.5 & 740 & 19.7 \\
\hline CU 1766 & 12 & $<0.3$ & 7.6 & 317 & 11.0 \\
\hline E 1084 & 2 & 4.7 & 7.2 & 808 & 12.5 \\
\hline E 1903 & 5 & 0.4 & 7.3 & 830 & 11.3 \\
\hline E 1904 & 2 & 0.5 & 7.0 & 1,040 & 13.6 \\
\hline E 1755 & 5 & $<0.3$ & 7.0 & 370 & 13.2 \\
\hline GS 216 & 2 & 2.1 & 7.2 & 1,100 & 12.6 \\
\hline GS 624 & 8 & 0.4 & 7.5 & 575 & 13.6 \\
\hline NI 1093 & 5 & 5.4 & 7.6 & 1,060 & 14.3 \\
\hline OL 264 & 2 & 0.6 & 7.4 & 655 & 15.8 \\
\hline OL 291 & 2 & 0.4 & 7.3 & 1,040 & 12.5 \\
\hline WO 351 & 2 & 2.6 & 7.5 & 465 & 12.1 \\
\hline WO 432 & 2 & 6.7 & 7.2 & 653 & 10.2 \\
\hline \multicolumn{6}{|c|}{ Bedrock wells } \\
\hline CT 806 & 8 & -- & 7.4 & 383 & 10.8 \\
\hline CT 819 & 10 & 0.5 & 7.3 & 333 & 14.7 \\
\hline СТ 922 & 2 & 3.2 & 7.7 & 171 & 15.1 \\
\hline СТ 994 & 8 & 0.4 & 8.2 & 531 & 17.7 \\
\hline CT 1071 & 8 & 0.7 & 7.6 & 480 & 11.2 \\
\hline CU 1304 & 8 & -- & 8.0 & 603 & 14.1 \\
\hline CU 1951 & 2 & -- & 7.5 & 464 & 12.6 \\
\hline CU 2054 & 10 & 0.4 & 7.3 & 303 & 13.0 \\
\hline CU 2158 & 2 & 3.5 & 7.0 & 1,260 & 16.7 \\
\hline CU 2195 & 2 & 3.3 & 7.1 & 576 & 13.2 \\
\hline E 1430 & 2 & 0.5 & 7.4 & 1,030 & 12.9 \\
\hline E 1507 & 8 & 0.6 & 7.4 & 461 & 16.0 \\
\hline E 2428 & 5 & 0.5 & 7.4 & 350 & 13.4 \\
\hline Е 2642 & 5 & -- & 7.2 & 1,370 & 11.9 \\
\hline MO 1406 & 5 & 0.7 & 7.4 & 851 & 17.7 \\
\hline MO 1594 & 5 & $<0.3$ & 7.1 & 1,850 & 17.3 \\
\hline NI 1203 & 2 & 1.1 & 7.5 & 5,500 & 14.4 \\
\hline OL 19 & 2 & 1.0 & 7.1 & 765 & 12.3 \\
\hline
\end{tabular}

${ }^{1}$ Two-letter prefix denotes county: AG, Allegany; CT, Cattaraugus; CU, Chatauqua; E, Erie; GS, Genesee; MO, Monroe; NI, Niagara; OL, Orleans; WO, Wyoming; number is local well-identification number assigned by U.S. Geological Survey. 
Table A4. Concentrations of inorganic constituents in ground-water samples from western New York study area, 2006.

[Well locations are shown in figure 1. mg/L, milligrams per liter; (00900), USGS National Water Information System (NWIS) parameter code. Bold values exceed one or more drinking-water standard]

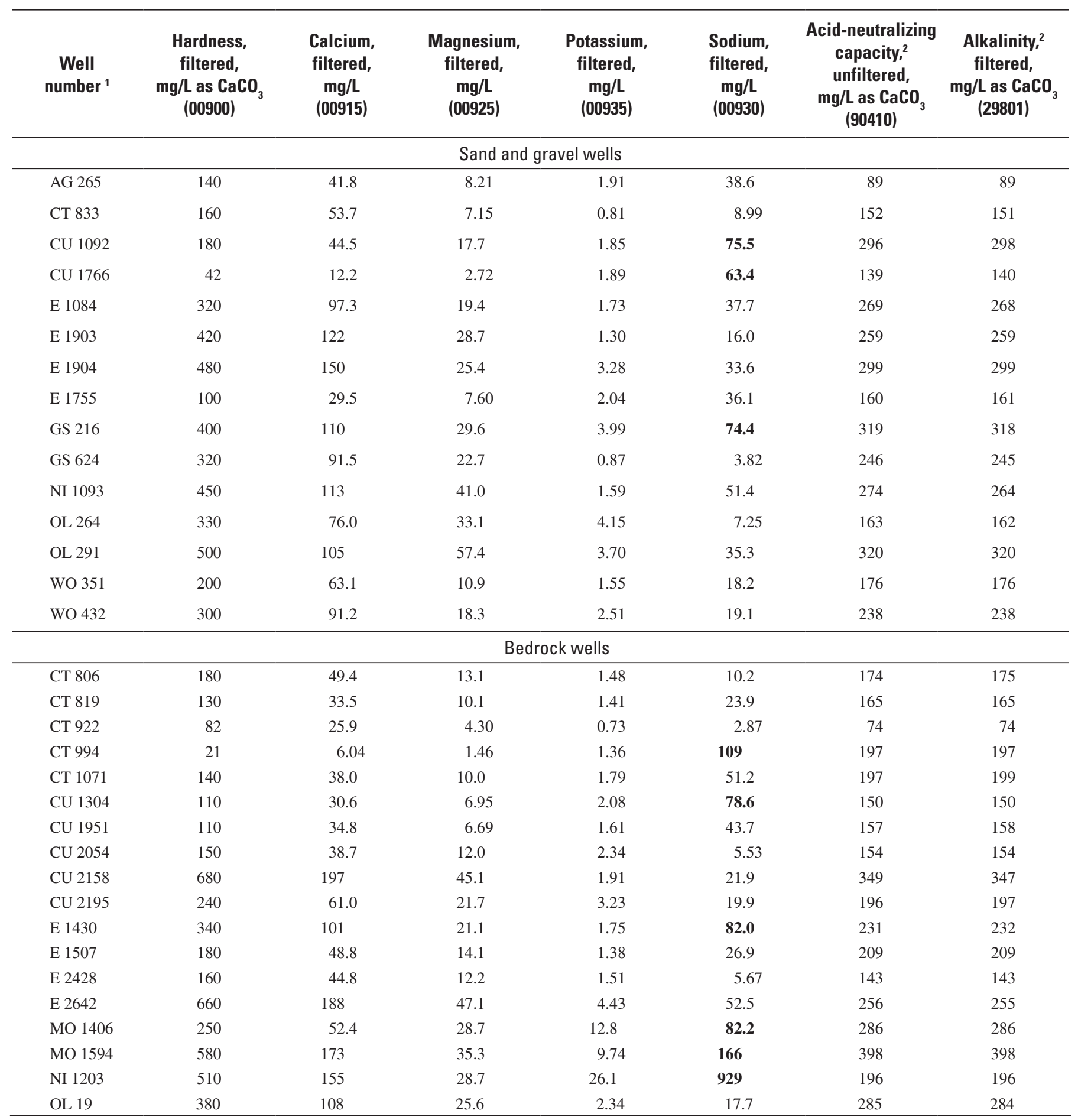

${ }^{1}$ Two-letter prefix denotes county: AG, Allegany; CT, Cattaraugus; CU, Chatauqua; E, Erie; GS, Genesee; MO, Monroe; NI, Niagara; OL, Orleans; WO, Wyoming; number is local well-identification number assigned by U.S. Geological Survey.

${ }^{2}$ Fixed-endpoint titration at $\mathrm{pH} 4.5$.

${ }^{3}$ Calculated from alkalinity. 
Table A4. Concentrations of inorganic constituents in ground-water samples from western New York study area, 2006.—Continued

[Well locations are shown in figure 1. mg/L, milligrams per liter; (29805), USGS National Water Information System (NWIS) parameter code; <, less than; E, estimated value — constituent was detected in the sample but with low or inconsistent recovery. Bold values exceed one or more drinking-water standard]

\begin{tabular}{|c|c|c|c|c|c|c|}
\hline $\begin{array}{c}\text { Well } \\
\text { number }{ }^{1}\end{array}$ & $\begin{array}{l}\text { Bicarbonate, } \\
\text { filtered, } \\
\mathrm{mg} / \mathrm{L} \text { as CaCO } \\
\text { (29805) }\end{array}$ & $\begin{array}{c}\text { Chloride, } \\
\text { filtered, } \\
\text { mg/L } \\
(00940)\end{array}$ & $\begin{array}{c}\text { Fluoride, } \\
\text { filtered, } \\
\text { mg/L } \\
(00950)\end{array}$ & $\begin{array}{c}\text { Silica, } \\
\text { filtered, } \\
\mathrm{mg} / \mathrm{L} \\
(00955)\end{array}$ & $\begin{array}{c}\text { Sulfate, } \\
\text { filtered, } \\
\mathrm{mg} / \mathrm{L} \\
(00945)\end{array}$ & $\begin{array}{c}\text { Residue on } \\
\text { evaporation, } \\
\text { at } 180^{\circ} \text { Celsius, } \\
\text { filtered, } \mathrm{mg} / \mathrm{L} \\
(70300)\end{array}$ \\
\hline \multicolumn{7}{|c|}{ Sand and gravel wells } \\
\hline AG 265 & 109 & 88.0 & E 0.08 & 6.31 & 12.9 & 272 \\
\hline CU 1092 & 364 & 56.6 & 0.41 & 5.96 & $<0.18$ & 403 \\
\hline CU 1766 & 171 & 37.4 & 0.57 & 8.88 & 1.69 & 225 \\
\hline E 1084 & 327 & 71.3 & E 0.09 & 10.1 & 30.9 & 456 \\
\hline E 1903 & 316 & 37.9 & $<0.10$ & 11.8 & 136 & 534 \\
\hline GS 624 & 299 & 10.8 & Е 0.07 & 14.5 & 60.8 & 362 \\
\hline NI 1093 & 322 & 91.7 & 0.15 & 16.2 & 120 & 650 \\
\hline OL 264 & 198 & 26.6 & 0.69 & 9.99 & 121 & 403 \\
\hline OL 291 & 390 & 85.9 & 0.22 & 19.5 & 130 & 652 \\
\hline WO 351 & 215 & 29.9 & Е 0.09 & 6.75 & 17.7 & 258 \\
\hline WO 432 & 290 & 38.6 & E 0.07 & 7.25 & 25.4 & 366 \\
\hline \multicolumn{7}{|c|}{ Bedrock wells } \\
\hline СТ 806 & 214 & 3.91 & 0.13 & 10.5 & 26.8 & 223 \\
\hline CU 1951 & 193 & 44.6 & 0.29 & 9.29 & 5.33 & 251 \\
\hline CU 2054 & 188 & 0.96 & 0.27 & 16.1 & 9.30 & 187 \\
\hline CU 2158 & 423 & 22.2 & 0.17 & 11.0 & 345 & 922 \\
\hline CU 2195 & 240 & 61.8 & 0.39 & 16.8 & 8.36 & 317 \\
\hline E 1430 & 283 & 141 & 0.16 & 15.2 & 81.0 & 615 \\
\hline E 1507 & 255 & 10.1 & 0.33 & 12.3 & 24.4 & 259 \\
\hline Е 2428 & 174 & 20.2 & 0.28 & 15.1 & 7.59 & 195 \\
\hline Е 2642 & 311 & 93.6 & 0.73 & 6.58 & 371 & 952 \\
\hline MO 1406 & 349 & 78.7 & 0.28 & 13.8 & 54.4 & 490 \\
\hline MO 1594 & 486 & 340 & 0.17 & 8.05 & 87.0 & 1,070 \\
\hline NI 1203 & 239 & 1,590 & 0.77 & 8.41 & 271 & 3,250 \\
\hline OL 19 & 346 & 41.5 & 0.11 & 11.8 & 63.3 & 462 \\
\hline
\end{tabular}

${ }^{1}$ Two-letter prefix denotes county: AG, Allegany; CT, Cattaraugus; CU, Chatauqua; E, Erie; GS, Genesee; MO, Monroe; NI, Niagara; OL, Orleans; WO, Wyoming; number is local well-identification number assigned by U.S. Geological Survey. 
Table A5. Concentrations of nutrients and total organic carbon in ground-water samples from western New York study area, 2006.

[Well locations are shown in figure 1. mg/L, milligrams per liter; N, nitrogen; P, phosphorus; <, less than; (00623), National Water Information System (NWIS) parameter code; E, estimated value — constituent was detected in the sample but with low or inconsistent recovery]

\begin{tabular}{|c|c|c|c|c|c|c|}
\hline $\begin{array}{c}\text { Well } \\
\text { number }^{1}\end{array}$ & $\begin{array}{l}\text { Ammonia plus } \\
\text { organic nitrogen, } \\
\text { filtered, } \\
\text { mg/L as N } \\
\text { (00623) }\end{array}$ & $\begin{array}{c}\text { Ammonia, } \\
\text { filtered, } \\
\text { mg/L as N } \\
\text { (00608) }\end{array}$ & $\begin{array}{l}\text { Nitrate plus } \\
\text { nitrite, } \\
\text { filtered, } \\
\text { mg/L as N } \\
\text { (00631) }\end{array}$ & $\begin{array}{c}\text { Nitrite, } \\
\text { filtered, } \\
\text { mg/L as N } \\
\text { (00613) }\end{array}$ & $\begin{array}{c}\text { Orthophosphate, } \\
\text { filtered, } \\
\text { mg/L as } P \\
\text { (00671) }\end{array}$ & $\begin{array}{c}\text { Total organic } \\
\text { carbon, } \\
\text { unfiltered, } \\
\text { mg/L } \\
(00680)\end{array}$ \\
\hline \multicolumn{7}{|c|}{ Sand and gravel wells } \\
\hline AG 265 & E 0.06 & $<0.020$ & 2.40 & $<0.002$ & 0.012 & $<1.0$ \\
\hline CU 1092 & 3.1 & 3.00 & $<0.06$ & $<0.002$ & 0.109 & 1.8 \\
\hline CU 1766 & 0.46 & 0.465 & $<0.06$ & $<0.002$ & 0.008 & $<1.0$ \\
\hline E 1084 & E 0.07 & E 0.010 & 4.58 & $<0.002$ & E 0.004 & $<1.0$ \\
\hline E 1903 & E 0.10 & 0.055 & $<0.06$ & $<0.002$ & 0.006 & $<1.0$ \\
\hline GS 624 & E 0.10 & 0.054 & $<0.06$ & $<0.002$ & 0.009 & $<1.0$ \\
\hline NI 1093 & 0.34 & Е 0.019 & $<0.06$ & $<0.002$ & E 0.004 & $<1.0$ \\
\hline OL 264 & 0.19 & 0.074 & 2.59 & 0.208 & $<0.006$ & $<1.0$ \\
\hline OL 291 & 0.17 & 0.078 & $<0.06$ & $<0.002$ & E 0.005 & 1.3 \\
\hline WO 351 & $<0.10$ & $<0.020$ & 1.38 & $<0.002$ & 0.006 & $<1.0$ \\
\hline WO 432 & E 0.07 & $<0.020$ & 6.92 & $<0.002$ & E 0.003 & $<1.0$ \\
\hline \multicolumn{7}{|c|}{ Bedrock wells } \\
\hline CT 806 & $<0.10$ & 0.015 & $<0.06$ & $<0.002$ & E 0.004 & $<1.0$ \\
\hline CU 2054 & Е 0.07 & 0.042 & $<0.06$ & $<0.002$ & 0.011 & $<1.0$ \\
\hline CU 2158 & 0.25 & 0.073 & 0.12 & $<0.002$ & $<0.006$ & $<1.0$ \\
\hline CU 2195 & 0.27 & 0.057 & 0.96 & 0.005 & 0.009 & 1.1 \\
\hline E 1430 & 0.81 & 0.684 & $<0.06$ & $<0.002$ & 0.009 & 1.1 \\
\hline E 1507 & 0.53 & 0.411 & $<0.06$ & $<0.002$ & 0.007 & $<1.0$ \\
\hline E 2428 & 0.43 & 0.355 & $<0.06$ & $<0.002$ & 0.006 & $<1.0$ \\
\hline E 2642 & 0.61 & $<0.020$ & $<0.06$ & E 0.001 & $<0.006$ & 1.6 \\
\hline MO 1406 & 0.83 & 0.727 & $<0.06$ & $<0.002$ & 0.008 & 2.4 \\
\hline MO 1594 & 0.16 & 0.018 & E 0.04 & 0.006 & E 0.005 & 3.6 \\
\hline NI 1203 & 2.8 & 2.61 & $<0.06$ & E 0.002 & E 0.006 & 1.5 \\
\hline OL 19 & E 0.09 & E 0.016 & 2.33 & $<0.002$ & 0.006 & 1.2 \\
\hline
\end{tabular}

${ }^{1}$ Two-letter prefix denotes county: AG, Allegany; CT, Cattaraugus; CU, Chatauqua; E, Erie; GS, Genesee; MO, Monroe; NI, Niagara; OL, Orleans; WO, Wyoming; number is local well-identification number assigned by U.S. Geological Survey. 
Table A6. Concentrations of trace elements and radon-222 in ground-water samples from western New York study area, 2006.

[Well locations are shown in figure 1. $\mu \mathrm{g} / \mathrm{L}$, micrograms per liter; (01105), USGS National Water Information System (NWIS) parameter code; <, less than; E, estimated value — constituent was detected in the sample but with low or inconsistent recovery. Bold values exceed one or more drinking-water standard]

\begin{tabular}{|c|c|c|c|c|c|c|c|c|}
\hline $\begin{array}{c}\text { Well } \\
\text { number }{ }^{1}\end{array}$ & $\begin{array}{c}\text { Aluminum, } \\
\text { unfiltered, } \\
\mu \mathrm{g} / \mathrm{L} \\
(01105)\end{array}$ & $\begin{array}{c}\text { Antimony, } \\
\text { unfiltered, } \\
\mu \mathrm{g} / \mathrm{L} \\
(01097)\end{array}$ & $\begin{array}{c}\text { Arsenic, } \\
\text { unfiltered, } \\
\mu \mathrm{g} / \mathrm{L} \\
(01002)\end{array}$ & $\begin{array}{c}\text { Barium, } \\
\text { unfiltered, } \\
\mu \mathrm{g} / \mathrm{L} \\
(01007)\end{array}$ & $\begin{array}{c}\text { Beryllium, } \\
\text { unfiltered, } \\
\mu \mathrm{g} / \mathrm{L} \\
(01012)\end{array}$ & $\begin{array}{c}\text { Boron, } \\
\text { filtered, } \\
\mu \mathrm{g} / \mathrm{L} \\
(01020)\end{array}$ & $\begin{array}{c}\text { Cadmium, } \\
\text { unfiltered, } \\
\mu \mathrm{g} / \mathrm{L} \\
(01027)\end{array}$ & $\begin{array}{c}\text { Chromium, } \\
\text { unfiltered, } \\
\mu \mathrm{g} / \mathrm{L} \\
(01034)\end{array}$ \\
\hline \multicolumn{9}{|c|}{ Sand and gravel wells } \\
\hline AG 265 & $<2$ & E 0.1 & 2.2 & 124 & $<0.06$ & 32 & 0.02 & $<0.60$ \\
\hline CT 833 & E 1 & $<0.2$ & 0.32 & 236 & $<0.06$ & 12 & $<0.04$ & 0.22 \\
\hline CU 1092 & 5 & $<0.2$ & 111 & 817 & $<0.06$ & 222 & $<0.04$ & 0.12 \\
\hline CU 1766 & 2 & $<0.2$ & $<0.12$ & 412 & $<0.06$ & 365 & $<0.04$ & 0.14 \\
\hline E 1084 & $<2$ & $<0.2$ & 0.42 & 175 & $<0.06$ & 32 & $<0.02$ & 1.1 \\
\hline E 1903 & E 2 & $<0.2$ & 0.24 & 48.1 & $<0.06$ & 52 & $<0.02$ & $<0.60$ \\
\hline E 1904 & $<2$ & $<0.2$ & 0.41 & 153 & $<0.06$ & 71 & E 0.01 & $<0.60$ \\
\hline E 1755 & 30 & $<0.2$ & Е 0.08 & 294 & $<0.06$ & 172 & $<0.04$ & 0.17 \\
\hline GS 216 & $<2$ & $<0.2$ & 1.3 & 178 & $<0.06$ & 55 & E 0.01 & E 0.40 \\
\hline GS 624 & 3 & $<0.2$ & Е 0.19 & 184 & $<0.06$ & 15 & 0.02 & $<0.60$ \\
\hline NI 1093 & 2 & Е 0.2 & 1.7 & 33.4 & $<0.06$ & 20 & $<0.02$ & 2.1 \\
\hline OL 264 & E 2 & 0.5 & 0.60 & 94.5 & $<0.06$ & 22 & 0.05 & $<0.60$ \\
\hline OL 291 & $<2$ & $<0.2$ & 4.2 & 79.2 & $<0.06$ & 92 & E 0.02 & $<0.60$ \\
\hline WO 351 & E 1 & $<0.2$ & 3.2 & 93.2 & $<0.06$ & 26 & $<0.02$ & $<0.60$ \\
\hline WO 432 & $<2$ & $<0.2$ & 1.1 & 99.1 & $<0.06$ & 18 & $<0.02$ & $<0.60$ \\
\hline \multicolumn{9}{|c|}{ Bedrock wells } \\
\hline CT 806 & 11 & $<0.2$ & 0.31 & 21.7 & $<0.06$ & 50 & $<0.04$ & 0.11 \\
\hline CT 819 & $<2$ & $<0.2$ & 3.6 & 84.1 & $<0.06$ & 106 & $<0.04$ & 0.13 \\
\hline СТ 922 & E 2 & $<0.2$ & 0.42 & 36.0 & $<0.06$ & 13 & $<0.04$ & 0.13 \\
\hline CT 994 & E 1 & $<0.2$ & Е 0.06 & 276 & $<0.06$ & 292 & $<0.04$ & 0.10 \\
\hline CT 1071 & E 2 & $<0.2$ & 0.79 & 56.2 & $<0.06$ & 185 & $<0.04$ & 0.15 \\
\hline CU 1304 & E 1 & $<0.2$ & 0.75 & 1,660 & $<0.06$ & 157 & $<0.04$ & 0.12 \\
\hline CU 1951 & 5 & $<0.2$ & 0.97 & 1,410 & $<0.06$ & 182 & $<0.04$ & 0.08 \\
\hline CU 2054 & E 2 & $<0.2$ & 0.93 & 128 & $<0.06$ & 38 & $<0.04$ & 0.41 \\
\hline CU 2158 & 85 & 3.8 & 3.5 & 22.6 & 0.52 & 51 & 4.02 & 1.8 \\
\hline CU 2195 & 29 & $<0.2$ & 0.47 & 873 & $<0.06$ & 154 & $<0.02$ & $<0.60$ \\
\hline E 1430 & $<2$ & $<0.2$ & 0.48 & 120 & $<0.06$ & 197 & $<0.02$ & $<0.60$ \\
\hline E 1507 & 7 & $<0.2$ & 0.34 & 607 & $<0.06$ & 120 & $<0.02$ & $<0.60$ \\
\hline E 2428 & E 1 & $<0.2$ & E 0.17 & 325 & $<0.06$ & 58 & $<0.02$ & $<0.60$ \\
\hline Е 2642 & $<2$ & 0.2 & 0.83 & 31.3 & $<0.06$ & 385 & $<0.09$ & 0.99 \\
\hline MO 1406 & $<2$ & $<0.2$ & 20.9 & 105 & $<0.06$ & 375 & 0.08 & $<0.04$ \\
\hline MO 1594 & 3 & $<0.2$ & 0.53 & 334 & $<0.06$ & 298 & 0.32 & $<0.04$ \\
\hline NI 1203 & $<6$ & $<0.6$ & 1.2 & 100 & $<0.18$ & 2,430 & 0.94 & $<0.12$ \\
\hline OL 19 & $<2$ & $<0.2$ & 2.2 & 119 & $<0.06$ & 35 & $<0.02$ & E. 38 \\
\hline
\end{tabular}

${ }^{1}$ Two-letter prefix denotes county: AG, Allegany; CT, Cattaraugus; CU, Chatauqua; E, Erie; GS, Genesee; MO, Monroe; NI, Niagara; OL, Orleans; WO, Wyoming; number is local well-identification number assigned by U.S. Geological Survey. 
Table A6. Concentrations of trace elements and radon-222 in ground-water samples from western New York study area, 2006.-Continued

[Well locations are shown in figure 1. $\mu \mathrm{g} / \mathrm{L}$, micrograms per liter; (01037), USGS National Water Information System (NWIS) parameter code; <, less than; E, estimated value_constituent was detected in the sample but with low or inconsistent recovery; Bold values exceed one or more drinking-water standard]

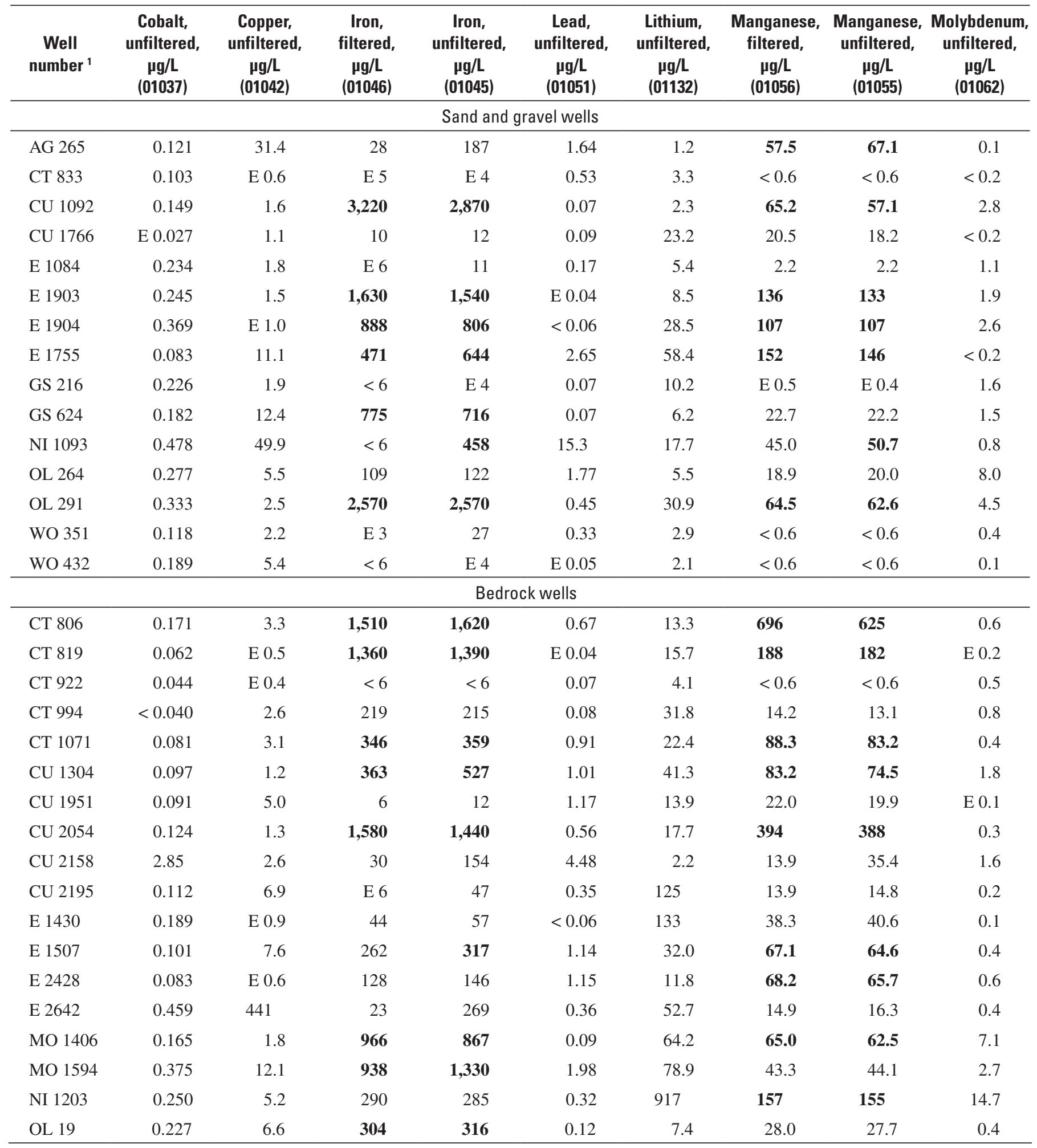

${ }^{1}$ Two-letter prefix denotes county: AG, Allegany; CT, Cattaraugus; CU, Chatauqua; E, Erie; GS, Genesee; MO, Monroe; NI, Niagara; OL, Orleans; WO, Wyoming; number is local well-identification number assigned by U.S. Geological Survey. 
Table A6. Concentrations of trace elements and radon-222 in ground-water samples from western New York study area, 2006.-Continued

[Well locations are shown in figure 1. $\mu \mathrm{g} / \mathrm{L}$, micrograms per liter; (01067), USGS National Water Information System (NWIS) parameter code; <, less than; E, estimated value — constituent was detected in the sample but with low or inconsistent recovery. Bold values exceed one or more drinking-water standard]

\begin{tabular}{|c|c|c|c|c|c|c|c|c|}
\hline $\begin{array}{c}\text { Well } \\
\text { number }^{1}\end{array}$ & $\begin{array}{c}\text { Nickel, } \\
\text { unfiltered, } \\
\mu \mathrm{g} / \mathrm{L} \\
(01067)\end{array}$ & $\begin{array}{c}\text { Selenium, } \\
\text { unfiltered, } \\
\mu \mathrm{g} / \mathrm{L} \\
(01147)\end{array}$ & $\begin{array}{c}\text { Silver, } \\
\text { unfiltered, } \\
\mu \mathrm{g} / \mathrm{L} \\
(01077)\end{array}$ & $\begin{array}{c}\text { Strontium, } \\
\text { unfiltered, } \\
\mu \mathrm{g} / \mathrm{L} \\
(\mathbf{0 1 0 8 2})\end{array}$ & $\begin{array}{c}\text { Thallium, } \\
\text { unfiltered, } \\
\mu \mathrm{g} / \mathrm{L} \\
(01059)\end{array}$ & $\begin{array}{c}\text { Radon-222, } \\
\text { unfiltered, } \\
\text { picocuries } \\
\text { per liter } \\
\text { (pCi/L) } \\
\text { (82303) }\end{array}$ & $\begin{array}{c}\text { Uranium, } \\
\text { (natural), } \\
\text { unfiltered, } \\
\mu \mathrm{g} / \mathrm{L} \\
(28011)\end{array}$ & $\begin{array}{c}\text { Zinc, } \\
\text { unfiltered, } \\
\mu \mathrm{g} / \mathrm{L} \\
(01092)\end{array}$ \\
\hline \multicolumn{9}{|c|}{ Sand and gravel wells } \\
\hline CT 833 & 0.53 & $<0.08$ & $<0.16$ & 90.2 & $<0.18$ & 780 & 0.083 & $<2$ \\
\hline CU 1092 & 0.83 & $<0.08$ & $<0.16$ & 976 & $<0.18$ & 770 & $<0.012$ & 31 \\
\hline CU 1766 & 0.32 & $<0.08$ & $<0.16$ & 163 & $<0.18$ & 670 & $<0.012$ & E 2 \\
\hline E 1084 & 2.15 & 0.16 & $<0.02$ & 145 & $<0.18$ & 500 & 0.618 & 3 \\
\hline GS 216 & 0.87 & 0.80 & $<0.02$ & 364 & $<0.18$ & 470 & 0.837 & 7 \\
\hline GS 624 & 0.75 & $<0.08$ & $<0.02$ & 191 & $<0.18$ & 160 & 0.016 & 13 \\
\hline NI 1093 & 2.33 & Е 0.06 & 0.02 & 244 & $<0.18$ & 40 & 0.842 & 30 \\
\hline OL 264 & 1.42 & E 0.05 & $<0.02$ & 370 & $<0.18$ & 500 & 2.80 & 25 \\
\hline OL 291 & 0.96 & $<0.08$ & $<0.02$ & 693 & $<0.18$ & 1,140 & 3.47 & 2 \\
\hline WO 351 & 0.31 & 0.23 & $<0.02$ & 111 & $<0.18$ & 680 & 0.170 & 3 \\
\hline WO 432 & 0.56 & 0.18 & $<0.02$ & 115 & $<0.18$ & 590 & 0.152 & E 2 \\
\hline \multicolumn{9}{|c|}{ Bedrock wells } \\
\hline CU 1951 & 0.33 & $<0.08$ & $<0.16$ & 251 & $<0.18$ & 940 & 0.119 & 4 \\
\hline CU 2054 & 0.41 & $<0.08$ & $<0.16$ & 220 & $<0.18$ & 580 & 0.093 & E 2 \\
\hline CU 2158 & 0.81 & 1.6 & 2.23 & 60.6 & 0.45 & 480 & 1.27 & 62 \\
\hline CU 2195 & 0.45 & Е 0.06 & $<0.02$ & 550 & $<0.18$ & 70 & 0.018 & 32 \\
\hline E 1430 & 1.15 & $<0.08$ & $<0.02$ & 1,090 & $<0.18$ & 170 & $<0.012$ & E 1 \\
\hline E 1507 & 0.43 & Е 0.04 & $<0.02$ & 346 & $<0.18$ & 400 & $<0.012$ & 2 \\
\hline Е 2428 & 0.21 & $<0.08$ & $<0.02$ & 325 & $<0.18$ & 410 & $<0.012$ & E 2 \\
\hline Е 2642 & 8.66 & 0.08 & E 0.01 & 10,600 & $<0.18$ & 190 & 0.272 & 180 \\
\hline MO 1406 & 1.54 & $<0.08$ & $<0.16$ & 1,580 & $<0.18$ & 1,420 & 0.423 & 9 \\
\hline MO 1594 & 1.24 & 0.10 & $<0.16$ & 1,920 & $<0.18$ & 2,080 & 6.45 & 8 \\
\hline NI 1203 & 2.06 & $<0.24$ & $<0.48$ & 4,900 & $<0.54$ & 2,160 & 0.160 & 14 \\
\hline OL 19 & 0.66 & 0.27 & $<0.02$ & 189 & $<0.18$ & 540 & 0.720 & 6 \\
\hline
\end{tabular}

${ }^{1}$ Two-letter prefix denotes county: AG, Allegany; CT, Cattaraugus; CU,Chatauqua; E, Erie; GS, Genesee; MO, Monroe; NI, Niagara; OL, Orleans; WO, Wyoming; number is local well-identification number assigned by U.S. Geological Survey. 
Table A7. Concentrations of pesticides and caffeine detected in ground-water samples from western New York study area, 2006.

[Well locations are shown in figure 1. $\mu \mathrm{g} / \mathrm{L}$, micrograms per liter; <, less than; (04040), USGS National Water Information System (NWIS) parameter code; CEAT, 2-Chloro-6-ethylamino-4-amino-s-triazine; CIAT, 2-Chloro-4-isopropylamino-6-amino-s-triazine; ESA, ethanesulfanic acid; OA, oxanilic acid; E, estimated value-constituent was detected in the sample but with low or inconsistent recovery]

\begin{tabular}{|c|c|c|c|c|c|c|c|c|c|}
\hline $\begin{array}{c}\text { Well } \\
\text { number }{ }^{1}\end{array}$ & $\begin{array}{c}\text { CIAT, } \\
\text { filtered, } \\
\mu \mathrm{g} / \mathrm{L} \\
(04040)\end{array}$ & $\begin{array}{c}\text { CEAT, } \\
\text { filtered, } \\
\mu \mathrm{g} / \mathrm{L} \\
(04038)\end{array}$ & $\begin{array}{c}\text { 2-[(2-Ethyl- } \\
\text { 6-methylphenyl) } \\
\text { amino]2-oxo-ESA, } \\
\text { filtered, } \\
\mu \mathrm{g} / \mathrm{L} \\
(62850) \\
\end{array}$ & $\begin{array}{c}\text { Acetochlor } \\
3 r^{d} \text { amide, } \\
\text { filtered, } \\
\mu \mathrm{g} / \mathrm{L} \\
(63782)\end{array}$ & $\begin{array}{c}\text { Alachlor } \\
\text { ESA, } \\
\text { filtered, } \\
\mu \mathrm{g} / \mathrm{L} \\
\mathbf{( 5 0 0 0 9 )}\end{array}$ & $\begin{array}{c}\text { Alachlor, } \\
\text { filtered, } \\
\mu \mathrm{g} / \mathrm{L} \\
(46342)\end{array}$ & $\begin{array}{c}\text { Atrazine, } \\
\text { filtered, } \\
\mu \mathrm{g} / \mathrm{L} \\
(\mathbf{3 9 6 3 2})\end{array}$ & $\begin{array}{c}\text { Benfluralin, } \\
\text { filtered, } \\
\mu \mathrm{g} / \mathrm{L} \\
(\mathbf{8 2 6 7 3 )}\end{array}$ & $\begin{array}{c}\text { Caffeine, } \\
\text { filtered, } \\
\mu \mathrm{g} / \mathrm{L} \\
(50305)\end{array}$ \\
\hline \multicolumn{10}{|c|}{ Sand and gravel wells } \\
\hline AG 265 & $<0.014$ & $<0.08$ & $<0.02$ & $<0.02$ & $<0.02$ & $<0.005$ & $<0.007$ & $<0.006$ & $<0.040$ \\
\hline CT 833 & Е 0.004 & E 0.01 & $<0.02$ & $<0.02$ & $<0.02$ & $<0.005$ & $<0.007$ & $<0.010$ & $<0.018$ \\
\hline CU 1092 & $<0.014$ & $<0.08$ & $<0.02$ & $<0.02$ & $<0.02$ & $<0.005$ & $<0.007$ & $<0.010$ & $<0.018$ \\
\hline CU 1766 & $<0.014$ & $<0.08$ & $<0.02$ & $<0.02$ & $<0.02$ & $<0.005$ & $<0.007$ & $<0.010$ & Е 0.008 \\
\hline E 1084 & $<0.014$ & $<0.08$ & $<0.02$ & $<0.02$ & $<0.02$ & $<0.005$ & $<0.007$ & $<0.006$ & $<0.040$ \\
\hline E 1903 & $<0.014$ & $<0.08$ & $<0.02$ & $<0.02$ & $<0.02$ & $<0.005$ & $<0.007$ & $<0.006$ & $<0.040$ \\
\hline E 1904 & $<0.014$ & $<0.08$ & $<0.02$ & $<0.02$ & $<0.02$ & $<0.005$ & $<0.007$ & $<0.006$ & $<0.040$ \\
\hline E 1755 & $<0.014$ & $<0.08$ & $<0.02$ & $<0.02$ & $<0.02$ & $<0.005$ & $<0.007$ & $<0.010$ & $<0.018$ \\
\hline GS 216 & E 0.005 & $<0.08$ & $<0.02$ & $<0.02$ & $<0.02$ & $<0.005$ & $<0.007$ & $<0.006$ & $<0.040$ \\
\hline GS 624 & $<0.014$ & $<0.08$ & $<0.02$ & $<0.02$ & $<0.02$ & $<0.005$ & $<0.007$ & $<0.006$ & $<0.040$ \\
\hline NI 1093 & $<0.014$ & $<0.08$ & $<0.02$ & $<0.02$ & $<0.02$ & $<0.005$ & $<0.007$ & $<0.006$ & $<0.040$ \\
\hline OL 264 & Е 0.009 & $<0.08$ & 0.40 & $<0.02$ & 0.08 & $<0.005$ & $<0.007$ & $<0.006$ & $<0.040$ \\
\hline OL 291 & $<0.014$ & $<0.08$ & $<0.02$ & $<0.02$ & $<0.02$ & $<0.005$ & $<0.007$ & $<0.006$ & $<0.040$ \\
\hline WO 351 & Е 0.005 & $<0.08$ & $<0.02$ & $<0.02$ & $<0.02$ & $<0.005$ & $<0.007$ & $<0.006$ & $<0.040$ \\
\hline WO 432 & E 0.006 & $<0.08$ & $<0.02$ & $<0.02$ & 0.07 & $<0.005$ & $<0.007$ & $<0.006$ & $<0.040$ \\
\hline \multicolumn{10}{|c|}{ Bedrock wells } \\
\hline CT 806 & $<0.014$ & $<0.08$ & $<0.02$ & $<0.02$ & $<0.02$ & $<0.005$ & $<0.007$ & $<0.010$ & $<0.018$ \\
\hline СТ 819 & $<0.014$ & $<0.08$ & $<0.02$ & $<0.02$ & $<0.02$ & $<0.005$ & $<0.007$ & $<0.010$ & $<0.018$ \\
\hline СТ 922 & $<0.014$ & $<0.08$ & $<0.02$ & $<0.02$ & $<0.02$ & $<0.005$ & $<0.007$ & $<0.010$ & $<0.018$ \\
\hline СТ 994 & $<0.014$ & $<0.08$ & $<0.02$ & $<0.02$ & $<0.02$ & $<0.005$ & $<0.007$ & $<0.010$ & $<0.018$ \\
\hline CT 1071 & $<0.014$ & $<0.08$ & $<0.02$ & $<0.02$ & $<0.02$ & $<0.005$ & $<0.007$ & E 0.001 & $<0.018$ \\
\hline CU 1304 & $<0.014$ & $<0.08$ & $<0.02$ & $<0.02$ & $<0.02$ & $<0.005$ & $<0.007$ & $<0.010$ & $<0.018$ \\
\hline CU 1951 & $<0.014$ & $<0.08$ & $<0.02$ & $<0.02$ & $<0.02$ & $<0.005$ & $<0.007$ & $<0.010$ & $<0.018$ \\
\hline CU 2054 & $<0.014$ & $<0.08$ & $<0.02$ & $<0.02$ & $<0.02$ & $<0.005$ & $<0.007$ & E 0.001 & $<0.018$ \\
\hline CU 2158 & $<0.014$ & $<0.08$ & $<0.02$ & $<0.02$ & $<0.02$ & $<0.005$ & $<0.007$ & $<0.006$ & $<0.040$ \\
\hline CU 2195 & $<0.014$ & $<0.08$ & $<0.02$ & $<0.02$ & $<0.02$ & $<0.005$ & $<0.007$ & $<0.006$ & $<0.040$ \\
\hline E 1430 & $<0.014$ & $<0.08$ & $<0.02$ & $<0.02$ & $<0.02$ & $<0.005$ & $<0.007$ & $<0.006$ & $<0.040$ \\
\hline E 1507 & $<0.014$ & $<0.08$ & $<0.02$ & $<0.02$ & $<0.02$ & $<0.005$ & $<0.007$ & $<0.006$ & $<0.040$ \\
\hline E 2428 & $<0.014$ & $<0.08$ & $<0.02$ & $<0.02$ & $<0.02$ & $<0.005$ & $<0.007$ & $<0.006$ & $<0.040$ \\
\hline E 2642 & $<0.014$ & $<0.08$ & $<0.02$ & $<0.02$ & $<0.02$ & $<0.005$ & $<0.007$ & $<0.006$ & $<0.040$ \\
\hline MO 1406 & $<0.014$ & $<0.08$ & $<0.02$ & $<0.02$ & $<0.02$ & $<0.005$ & $<0.007$ & $<0.010$ & $<0.018$ \\
\hline MO 1594 & $<0.014$ & $<0.08$ & $<0.02$ & $<0.02$ & $<0.02$ & $<0.005$ & $<0.007$ & $<0.010$ & $<0.018$ \\
\hline NI 1203 & $<0.014$ & $<0.08$ & $<0.02$ & 0.10 & $<0.02$ & 1.03 & 0.104 & $<0.010$ & $<0.018$ \\
\hline OL 19 & Е 0.019 & $<0.08$ & $<0.02$ & $<0.02$ & 0.08 & $<0.005$ & 0.026 & $<0.006$ & $<0.040$ \\
\hline
\end{tabular}

${ }^{1}$ Two-letter prefix denotes county: AG, Allegany; CT, Cattaraugus; CU, Chatauqua; E, Erie; GS, Genesee; MO, Monroe; NI, Niagara; OL, Orleans; WO, Wyoming; number is local well-identification number assigned by U.S. Geological Survey. 
Table A7. Concentrations of pesticides and caffeine detected in ground-water samples from western New York study area, 2006.-Continued

[Well locations are shown in figure 1. $\mu \mathrm{g} / \mathrm{L}$, micrograms per liter; <, less than; (49308), USGS National Water Information System (NWIS) parameter code; CEAT, 2-Chloro-6-ethylamino-4-amino-s-triazine; CIAT, 2-Chloro-4-isopropylamino-6-amino-s-triazine; ESA, ethanesulfanic acid; OA, oxanilic acid; $\mathrm{E}$, estimated value - constituent was detected in the sample but with low or inconsistent recovery]

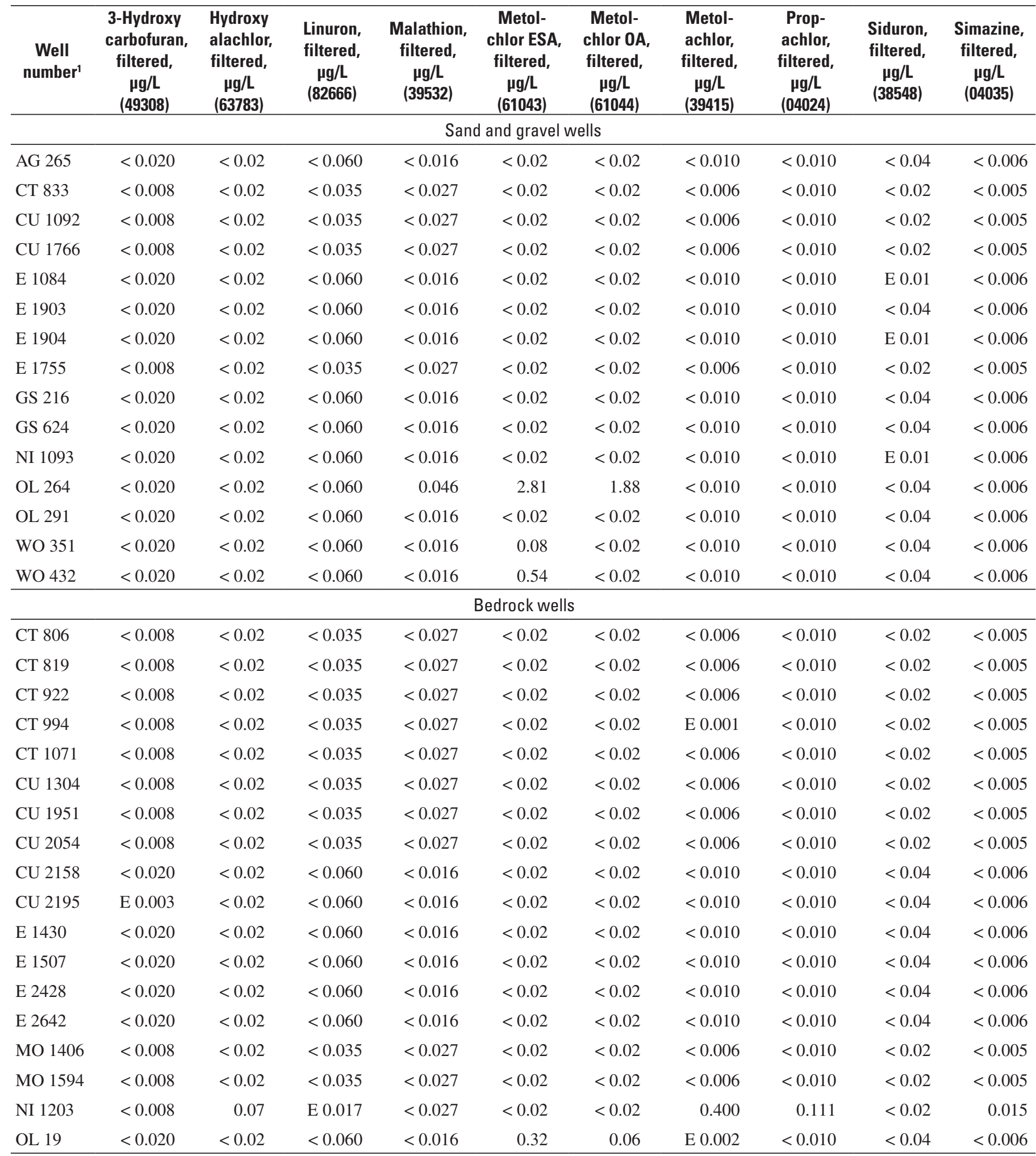

${ }^{1}$ Two-letter prefix denotes county: AG, Allegany; CT, Cattaraugus; CU, Chatauqua; E, Erie; GS, Genesee; MO, Monroe; NI, Niagara; OL, Orleans; WO, Wyoming; number is local well-identification number assigned by U.S. Geological Survey. 
Table A8. Concentrations of volatile organic compounds and phenolic compounds in ground-water samples from western New York study area, 2006.

[ Well locations are shown in figure 1. $\mu \mathrm{g} / \mathrm{L}$, micrograms per liter; <, less than; (32730), USGS National Water Information System parameter code; E, estimated value — constituent was detected in the sample but with low or inconsistent recovery]

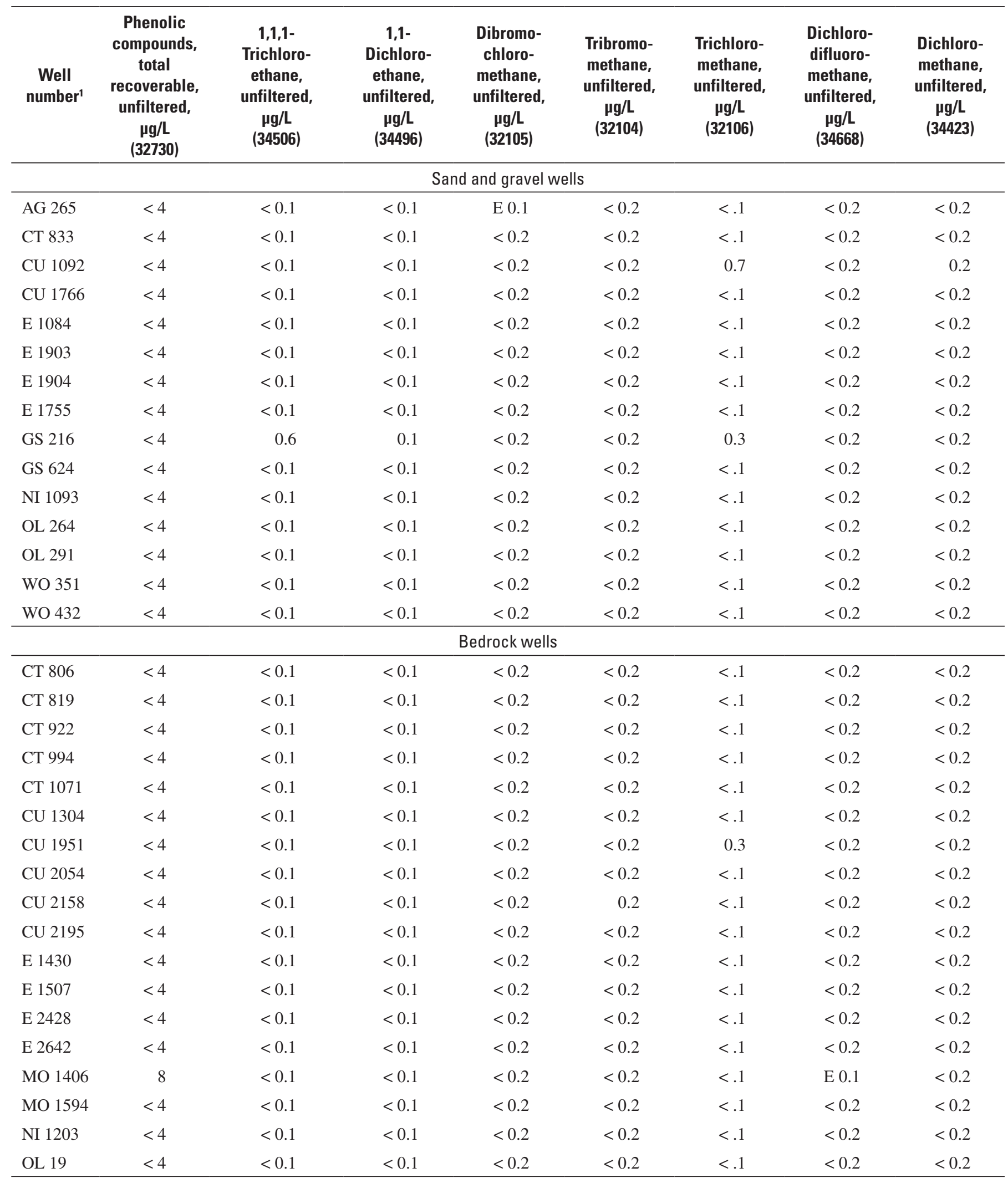

${ }^{1}$ Two-letter prefix denotes county: AG, Allegany; CT, Cattaraugus; CU, Chatauqua; E, Erie; GS, Genesee; MO, Monroe; NI, Niagara; OL, Orleans; WO, Wyoming; number is local well-identification number assigned by U.S. Geological Survey. 
Table A8. Concentrations of volatile organic compounds and total phenols in ground-water samples from western New York study area, 2006.-Continued

[ Well locations are shown in figure 1. $\mu \mathrm{g} / \mathrm{L}$, micrograms per liter; <, less than; (34371), USGS National Water Information System parameter code; E, estimated value — constituent was detected in the sample but with low or inconsistent recovery]

\begin{tabular}{|c|c|c|c|c|c|c|}
\hline $\begin{array}{c}\text { Well } \\
\text { number }\end{array}$ & $\begin{array}{c}\begin{array}{c}\text { Ethyl- } \\
\text { benzene, }\end{array} \\
\text { unfiltered, } \\
\mu \mathrm{g} / \mathrm{L} \\
(34371)\end{array}$ & $\begin{array}{c}m+p \\
\text { Xylene, } \\
\text { unfiltered, } \\
\mu \mathrm{g} / \mathrm{L} \\
(85795) \\
\end{array}$ & $\begin{array}{c}\text { o-Xylene, } \\
\text { unfiltered, } \\
\mu \mathrm{g} / \mathrm{L} \\
(77135)\end{array}$ & $\begin{array}{c}\text { Methyl tert- } \\
\text { butyl ether, } \\
\text { unfiltered, } \\
\mu \mathrm{g} / \mathrm{L} \\
(78032) \\
\end{array}$ & $\begin{array}{c}\text { Tetrachloro- } \\
\text { ethene, } \\
\text { unfiltered, } \\
\mu \mathrm{g} / \mathrm{L} \\
(34475) \\
\end{array}$ & $\begin{array}{c}\text { Trichloro- } \\
\text { ethene, } \\
\text { unfiltered, } \\
\mu \mathrm{g} / \mathrm{L} \\
(39180) \\
\end{array}$ \\
\hline \multicolumn{7}{|c|}{ Sand and gravel wells } \\
\hline AG 265 & $<0.1$ & $<0.2$ & $<0.1$ & $<0.2$ & 0.2 & $<0.1$ \\
\hline CT 833 & $<0.1$ & $<0.2$ & $<0.1$ & $<0.2$ & $<0.1$ & $<0.1$ \\
\hline CU 1092 & $<0.1$ & $<0.2$ & $<0.1$ & $<0.2$ & $<0.1$ & $<0.1$ \\
\hline CU 1766 & $<0.1$ & $<0.2$ & $<0.1$ & $<0.2$ & $<0.1$ & $<0.1$ \\
\hline E 1084 & $<0.1$ & $<0.2$ & $<0.1$ & $<0.2$ & $<0.1$ & $<0.1$ \\
\hline E 1903 & $<0.1$ & $<0.2$ & $<0.1$ & $<0.2$ & $<0.1$ & $<0.1$ \\
\hline E 1904 & $<0.1$ & $<0.2$ & $<0.1$ & 1.3 & $<0.1$ & $<0.1$ \\
\hline E 1755 & $<0.1$ & $<0.2$ & $<0.1$ & $<0.2$ & $<0.1$ & $<0.1$ \\
\hline GS 216 & $<0.1$ & $<0.2$ & $<0.1$ & $<0.2$ & 0.4 & 0.3 \\
\hline GS 624 & $<0.1$ & $<0.2$ & $<0.1$ & $<0.2$ & $<0.1$ & $<0.1$ \\
\hline NI 1093 & $<0.1$ & $<0.2$ & $<0.1$ & $<0.2$ & $<0.1$ & $<0.1$ \\
\hline OL 264 & 7.6 & 29.8 & 5.4 & $<0.2$ & $<0.1$ & $<0.1$ \\
\hline OL 291 & $<0.1$ & $<0.2$ & $<0.1$ & 0.3 & $<0.1$ & $<0.1$ \\
\hline WO 351 & $<0.1$ & $<0.2$ & $<0.1$ & $<0.2$ & $<0.1$ & $<0.1$ \\
\hline WO 432 & $<0.1$ & $<0.2$ & $<0.1$ & $<0.2$ & $<0.1$ & $<0.1$ \\
\hline \multicolumn{7}{|c|}{ Bedrock wells } \\
\hline СТ 806 & $<0.1$ & $<0.2$ & $<0.1$ & $<0.2$ & $<0.1$ & $<0.1$ \\
\hline СТ 819 & $<0.1$ & $<0.2$ & $<0.1$ & $<0.2$ & $<0.1$ & $<0.1$ \\
\hline СТ 922 & $<0.1$ & $<0.2$ & $<0.1$ & $<0.2$ & $<0.1$ & $<0.1$ \\
\hline СТ 994 & $<0.1$ & $<0.2$ & $<0.1$ & $<0.2$ & $<0.1$ & $<0.1$ \\
\hline CT 1071 & $<0.1$ & $<0.2$ & $<0.1$ & $<0.2$ & $<0.1$ & $<0.1$ \\
\hline CU 1304 & $<0.1$ & $<0.2$ & $<0.1$ & $<0.2$ & $<0.1$ & $<0.1$ \\
\hline CU 1951 & $<0.1$ & $<0.2$ & $<0.1$ & $<0.2$ & $<0.1$ & $<0.1$ \\
\hline CU 2054 & $<0.1$ & $<0.2$ & $<0.1$ & $<0.2$ & $<0.1$ & $<0.1$ \\
\hline CU 2158 & $<0.1$ & $<0.2$ & $<0.1$ & $<0.2$ & $<0.1$ & 0.2 \\
\hline CU 2195 & $<0.1$ & $<0.2$ & $<0.1$ & $<0.2$ & $<0.1$ & $<0.1$ \\
\hline E 1430 & $<0.1$ & $<0.2$ & $<0.1$ & $<0.2$ & $<0.1$ & $<0.1$ \\
\hline E 1507 & $<0.1$ & $<0.2$ & $<0.1$ & $<0.2$ & $<0.1$ & $<0.1$ \\
\hline E 2428 & $<0.1$ & Е 0.2 & $<0.1$ & $<0.2$ & $<0.1$ & $<0.1$ \\
\hline E 2642 & 1.8 & 7.4 & 2.2 & $<0.2$ & $<0.1$ & $<0.1$ \\
\hline MO 1406 & $<0.1$ & $<0.2$ & $<0.1$ & $<0.2$ & $<0.1$ & $<0.1$ \\
\hline MO 1594 & $<0.1$ & $<0.2$ & $<0.1$ & $<0.2$ & $<0.1$ & $<0.1$ \\
\hline NI 1203 & $<0.1$ & $<0.2$ & $<0.1$ & $<0.2$ & $<0.1$ & $<0.1$ \\
\hline OL 19 & $<0.1$ & $<0.2$ & $<0.1$ & $<0.2$ & $<0.1$ & $<0.1$ \\
\hline
\end{tabular}

${ }^{1}$ Two-letter prefix denotes county: AG, Allegany; CT, Cattaraugus; CU, Chatauqua; E, Erie; GS, Genesee; MO, Monroe; NI, Niagara; OL, Orleans; WO, Wyoming; number is local well-identification number assigned by U.S. Geological Survey. 
Table A9. Concentrations of bacteria in unfiltered ground-water samples from western New York study area, 2006.

[Well locations are shown in figure 1. mL, milliliter; <, less than; > greater than; CFU per mL, colony-forming units per milliliter; (61213), National Water Information System (NWIS) parameter code. Bold values exceed one or more drinking-water standard]

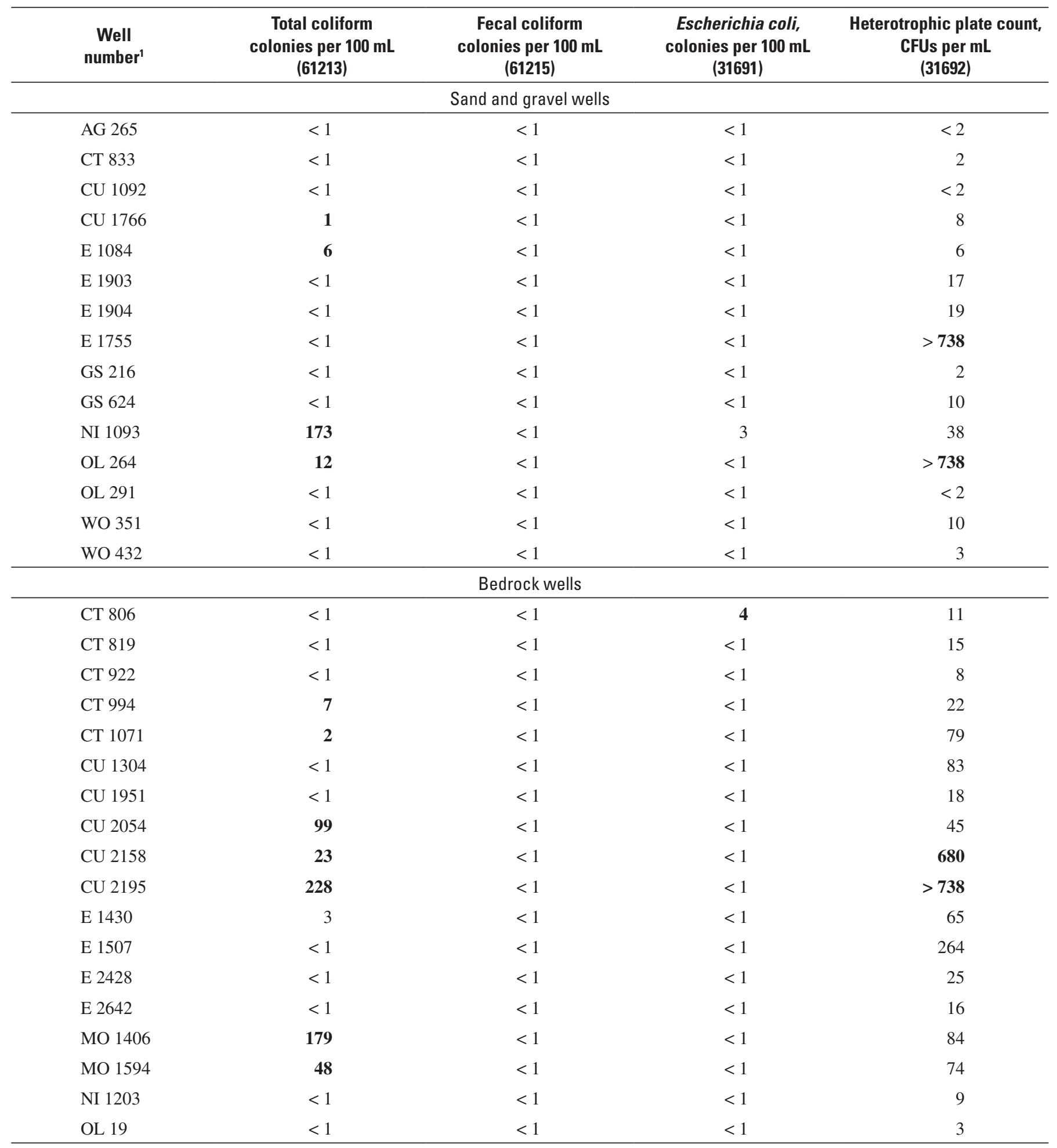

${ }^{1}$ Two-letter prefix denotes county: AG, Allegany; CT, Cattaraugus; CU, Chatauqua; E, Erie; GS, Genesee; MO, Monroe; NI, Niagara; OL, Orleans; WO, Wyoming; number is local well-identification number assigned by U.S. Geological Survey. 
For additional information write to: New York Water Science Center

U.S. Geological Survey

30 Brown Rd.

Ithaca, N.Y. 14850

Information requests:

(518) 285-5602

or visit our Web site at: http://ny.water.usgs.gov 


\section{䟢}

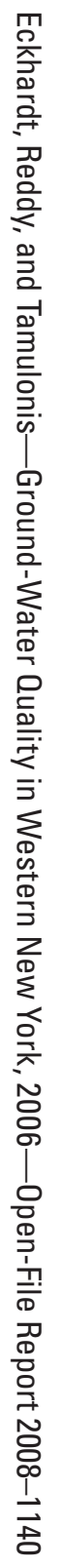

